\title{
Geological risk calculation through Probability of Success (PoS), applied to radioactive waste disposal in deep wells: A case study in the pre-Neogene basement in the Northern Croatia
}

\author{
Tomislav Malvić ${ }^{1, *}$, Maria Alzira Pimenta Dinis ${ }^{2, *}$, Josipa Velić ${ }^{1}$, Jasenka Sremac ${ }^{3}$, Josip \\ Ivšinović ${ }^{4}$, Marija Bošnjak ${ }^{5}$, Uroš Barudžija ${ }^{1}$, Želimir Veinović ${ }^{1}$ and Hélder Fernando Pedrosa
} e Sousa ${ }^{6}$

1 Faculty of Mining, Geology and Petroleum Engineering, University of Zagreb, Pierottijeva 6, HR 10000 Zagreb, Croatia; josipa.velic@rgn.hr ; uros.barudzija@rgn.hr (http://orcid.org/0000-0002-1617-9362) ; zelimir.veinovic@rgn.hr (http://orcid.org/0000-0002-1572-2191)

2 UFP Energy, Environment and Health Research Unit (FP-ENAS), University Fernando Pessoa, Praça 9 de Abril 349, 4249-004 Porto, Portugal; madinis@ufp.edu.pt (http://orcid.org/0000-0002-2198-6740)

3 Faculty of Science, University of Zagreb Horvatovac 102a, HR-10000 Zagreb, Croatia; jasenka.sremac@geol.pmf.hr (http://orcid.org/0000-0002-4736-7497)

4 INA-Industry of Oil Plc., Trg G. Szabe 1, HR-44310 Novska Zagreb, Croatia; josip.ivsinovic@ina.hr (http://orcid.org/0000-0002-7451-1677)

5 Croatian Natural History Museum, Demetrova ul. 1, HR-10000 Zagreb, Croatia; marija.bosnjak@hpm.hr (http://orcid.org/0000-0002-5050-0092)

6 Department of Mathematics (DM.UTAD), University of Trás-os-Montes and Alto Douro, Quinta de Prados, 5001-801 Vila Real, Portugal; hfps@utad.pt (http://orcid.org/0000-0002-2952-8859);

* Correspondence: tomislav.malvic@rgn.hr (T.M., http://orcid.org/0000-0003-2072-9539); madinis@ufp.edu.pt (M.A.P.D., http://orcid.org/0000-0002-2198-6740)

\begin{abstract}
The basic principles of geological risk calculation through Probability of Success (PoS) are mostly applied for numerical estimation of additional hydrocarbon existence in proven reservoirs or potential hydrocarbon discoveries in selected geological regional subsurface volume. It can be tailored and validated for a comprehensive input dataset collected in the selected petroleum province, adapted by dividing up geological events into several probability categories and classes. The most applied categories are (existence of) reservoir rocks, traps and isolators, source rocks, migration pathways and preservation conditions for hydrocarbons The methodology results in unique probability values as multiplication of independent statistical events, which can also be applied in the assessment of a potential hydrocarbon discovery of desired minimal volume and its value in any virtual currency like risk-neutral dollars. Such methodology has been extensively developed in the last decades in the Croatian subsurface, mostly in the Croatian part of the Pannonian Basin System (CPBS). Through the adaptation of geological categories, it was also applied in hybrid, i.e., stochastical, models developed in the CPBS (Drava Depression). Stochastically estimation of porosity was already applied. As the robustness of this methodology is very high, it was also modified to estimate the influence of water-flooding in increasing oil recovery in some proven Neogene sandstone reservoirs in the CPBS (Sava Depression). This new modification is being presented to be applied to geological risk calculation, intending to assess the safety of geological environment in deep wells, where depleted radioactive fuel would be disposed, a subject of great importance. The case study encompassed the magmatic and metamorphic rocks in the pre-Neogene basement of the CPBS. For disposal purpose, these are regionally lithologies considered as to be the safest ones considering petrophysical values, water saturation, recent weathering and tectonic activity.
\end{abstract}


Keywords: geological risk; pre-Neogene basement; radioactive waste; waste disposal; Northern Croatia; Probability of Success (PoS)

\section{Introduction}

Probability of Success (PoS) is a deterministic method by which deterministic estimation of independent categories within the system are analyzed in potential or proven reservoirs, or their selected properties. The main independent categories are: trap, reservoir, migration, source rock and preservation of hydrocarbons. They were determined on the basis of data from wells, logs, seismic interpretation, core analysis, stratigraphy and production of fluids.

It has been a longstanding application of the POS method in the Croatian Pannonian Basin System (CPBS). The first application in the CPBS was made on the example of Bjelovar Subdepression [1] for the member of the Moslavačka Gora Formation Bridge and the members of the Polo and Ashes of the Kloštar Ivanić Formation. Malvić [2] applied a deterministical-stochastical approach in PoS calculation of Badenian clastites of the Stari Gradac-Barcs Nyugat field (Drava Depression). Authors [3] calculated the value of PoS for "basement rocks and Miocene brecci" and "Upper Miocene sandstone" from Bjelovar Subdepression. Stochastically improved methodology for PoS calculation for Stari Gradac-Barcs Nyugat field (Drava Depression) are made by [4]. Deterministic assessment of independent categories within the system analyzes potential or proven reservoirs, or theirs selected properties (called custom geological probability). The mathematical expression for geological risk or geological probability (i.e., PoS, e..g, [1]) is presented in Equation 1:

$\operatorname{PoS}=p(t) \cdot p(r) \cdot p(m) \cdot p(s r) \cdot p(C H p)$

Where:

PoS - geological Probability of Success (\%);

$p(t) \quad$ - probability of potential traps $(\%)$;

$p(r) \quad$ - probability of reservoir characteristics (\%);

$p(m) \quad$ - the probability of hydrocarbon migration (\%);

$p(s r) \quad$ - the probability of the existence of source rocks (\%);

$\mathrm{p}(\mathrm{CHp})$ - the probability of hydrocarbon preservation (\%).

Using the values indicated (Figure 1.1) and the mathematical Equation 1.1, the geological risk is calculated for each observed stratigraphic interval. 


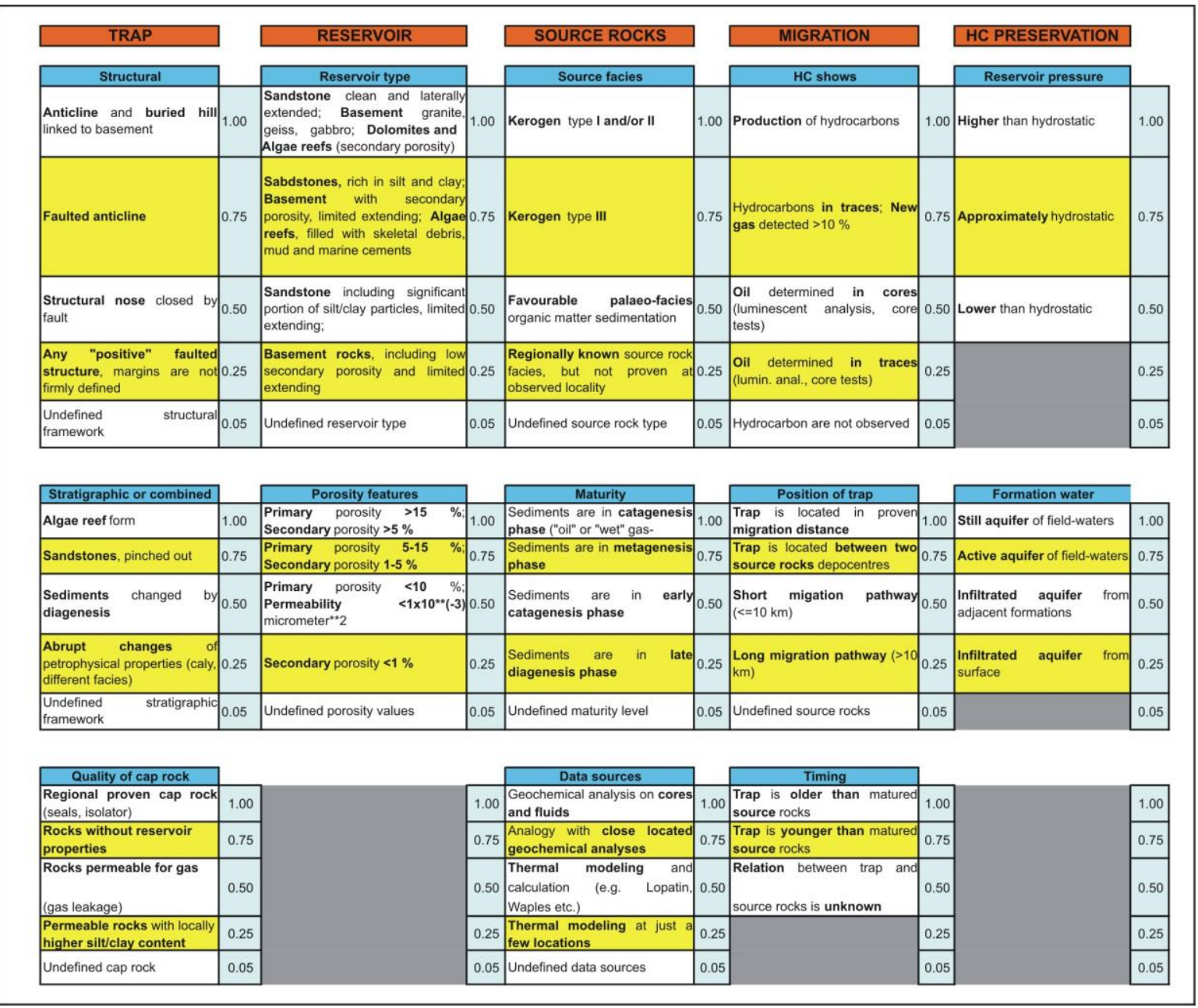

Figure 1.1. Geological categories and subcategories of PoS (e.g., [4]).

Novak Mavar 2015 calculated the geological probability of preserving the $\mathrm{CO}_{2}$ saturated reservoir in the Ivanic field (Sava Depression). The author made an assessment of the risk of migration through the sealing rocks of the oil-gas system into which $\mathrm{CO}_{2}$ is injected, which was previously saturated with oil and/or methane. As the size of $\mathrm{CO}_{2}$ and $\mathrm{CH}_{4}$ molecules is approximately the same, a methodology for estimating the possibility of $\mathrm{CH}_{4}$ migration through the same insulator rocks was used to determine the probability of $\mathrm{CO}_{2}$ retention in the reservoir. The results of the calculation of the probability of preservation of reservoir "Gamma series" of the Ivanić field indicate a certain event (the calculated value is 1.00). The obtained value is expected since it is an existing hydrocarbon deposit (Table 1.1).

Table 1.1. Selected values of subcategory probabilities for individual categories for reservoir "Gamma series" of the Ivanić oil and gas field (Sava Depression). Taken from [5].

\begin{tabular}{|c|c|c|c|}
\hline \multirow{2}{*}{ Categories } & Subcategories & $\begin{array}{c}\text { Probability of a } \\
\text { subcategory }\end{array}$ & $\begin{array}{c}\text { Probability } \\
\text { of category }\end{array}$ \\
\hline \multirow{2}{*}{ Trap } & Structural & 1.0 & 1.0 \\
\cline { 2 - 4 } & Quality of cap rock & 1.0 & 1.0 \\
\hline \multirow{2}{*}{ Reservoir } & Reservoir type & 1.0 & 1.0 \\
\cline { 2 - 4 } & Porosity features & 1.0 & 1.0 \\
\hline $\begin{array}{c}\text { Preservation of } \\
\text { hydrocarbons }\end{array}$ & Reservoir pressure & 1.0 & 1.0 \\
\hline
\end{tabular}


Authors [6] used the PoS method to calculate the probability of finding new gas discoveries in the wider area of Ivana and Ika Gas Fields (Northern Adriatic, Croatia). Režić \& Varenina [7] have designed a computer program for the calculation of PoS used for the probability assessment of new gas discoveries in the Croatian part of the Po Depression. The algorithm for calculating PoS in the Northern Adriatic is shown in Figure 1.2. Values for PoS and $p$ are selected as categorical probabilities from the interval 0-1. According to [7], a PoS value of 0.2 is the cut-off value based on which it is decided whether or not further research will be conducted in the CPBS area for the Upper Miocene reservoirs.

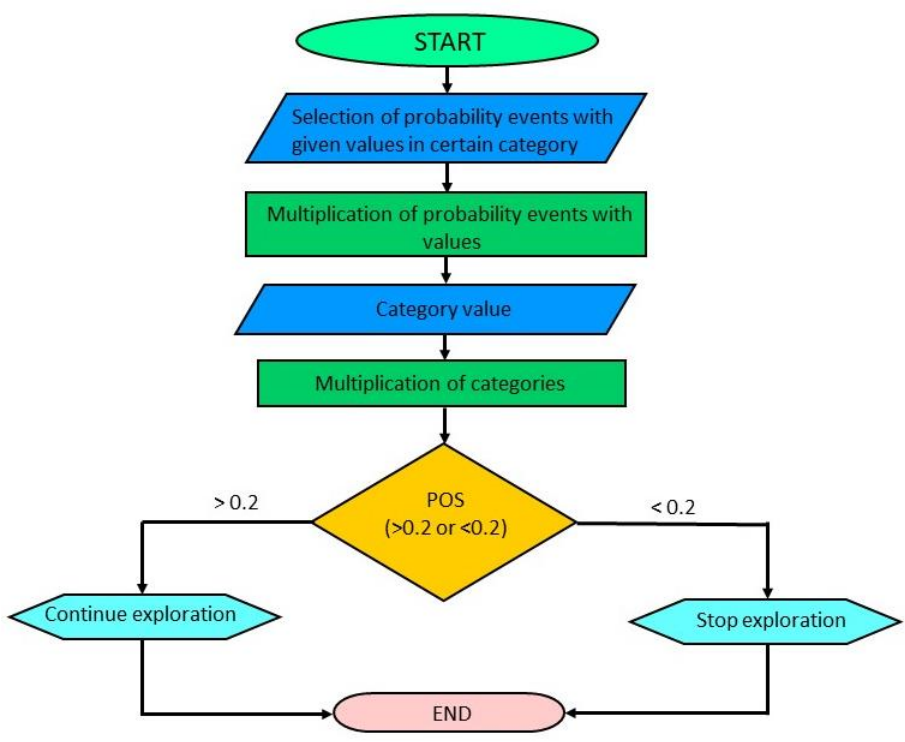

Figure 1.2. The PoS algorithm of [7].

The methodology for determining geological probability was applied in calculating the persistence of the remaining economic quantities of hydrocarbons in the western part of the Sava Depression by [8]. The western part of the Sava Depression is a relatively well-explored area with a large number of wells and discovered hydrocarbon reserves. The values of individual categories and subcategories of PoS are deterministically determined and the results are shown in Table 1.2. The calculated value of PoS for the western part of the Sava Depression is 0.4218 .

Table 1.2. Values of subcategory probabilities for individual categories for the western part of Sava Depression. Taken from [8].

\begin{tabular}{|c|c|c|c|}
\hline Categories & Subcategories & $\begin{array}{c}\text { Probability of a } \\
\text { subcategory }\end{array}$ & $\begin{array}{c}\text { Probability of } \\
\text { category }\end{array}$ \\
\hline \multirow{3}{*}{ Trap } & Structural & 1.0 & \multirow{3}{*}{0.75} \\
\hline & Stratigraphic or combined & 0.75 & \\
\hline & Quality of cap rock & 1.0 & \\
\hline \multirow{2}{*}{ Reservoir } & Reservoir type & 1.0 & \multirow{2}{*}{1.0} \\
\hline & Porosity features & 1.0 & \\
\hline \multirow{3}{*}{ Source rocks } & Source facies & 0.75 & \multirow{3}{*}{0.75} \\
\hline & Maturity & 1.0 & \\
\hline & Data sources & 1.0 & \\
\hline \multirow{3}{*}{ Migration } & Hydrocarbon shows & 1.0 & \multirow{3}{*}{1.0} \\
\hline & Position of trap & 1.0 & \\
\hline & Timing & 1.0 & \\
\hline \multirow{2}{*}{$\begin{array}{l}\text { Preservation of } \\
\text { hydrocarbons }\end{array}$} & Reservoir pressure & 0.75 & \multirow{2}{*}{0.75} \\
\hline & Formation water & 1.0 & \\
\hline
\end{tabular}


Recently, [9] modified PoS applied for assessment of water injection success in the western part of the Sava Depression.

\section{Geological samples of the pre-Neogene basement rocks in the Northern Croatia}

Lithological characteristics for two characteristic groups of rocks in the pre-Neogene basement, sedimentary carbonates and metamorphic rocks, taken from the outcrops in Medvednica Mt., are described, serving as the analogues for similar lithologies found in the deep wells of the CPBS. Geological relationships of the Neogene deposits and the metamorphic rocks in the central part, as well as with the sedimentary carbonate rocks in the southwestern part of the Medvednica Mt., are shown in Figure 2.1 [10].

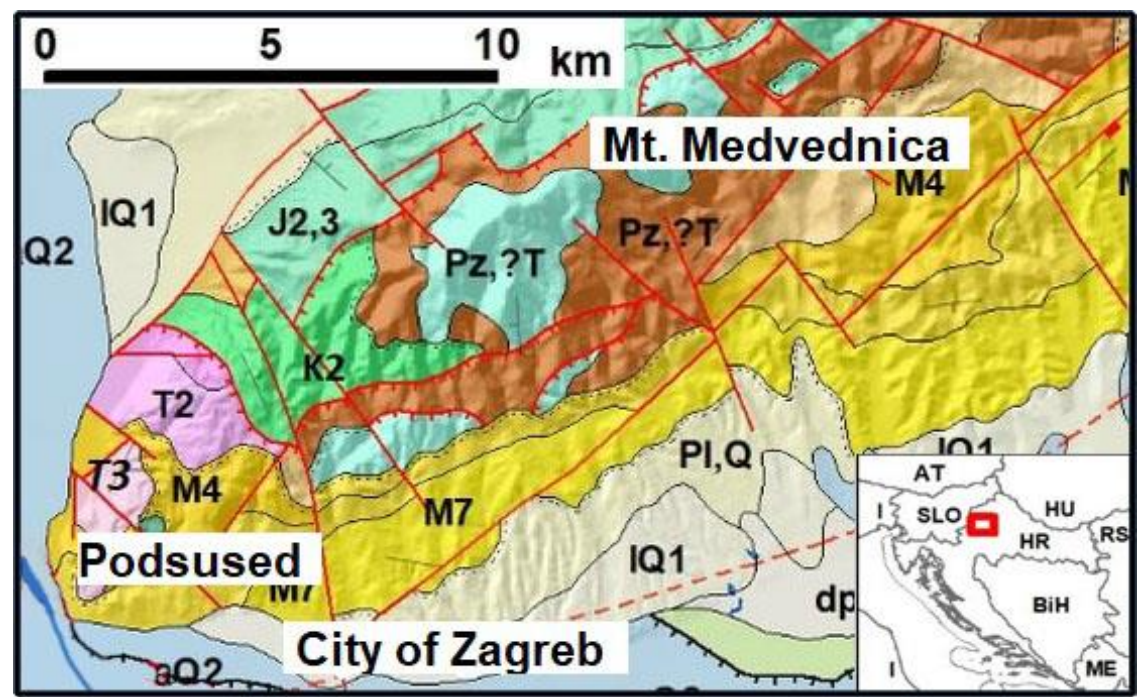

Figure 2.1. Geological relationships of the Neogene deposits and the pre-Neogene basement rocks in the central and SW parts of Medvednica Mt. Legend for geology, after [11]: Pz, ?T-P - Palaeozoic to Triassic parametamorphites; T2 - Middle Triassic limestones and dolomites; T3 - Upper Triassic dolomites; K2 - Upper

Cretaceous carbonate clastics; M4, M7 - Neogene deposits Pl,Q, Q1, Q2 - Plio-Quaternary deposits.

Sedimentary carbonate rocks found in the pre-Neogene basement of the CPBS are mainly Middle and Upper Triassic marine limestones and dolomites, which are well described at the outcrops in Medvednica Mt. [12-15], as well in the neighboring Samoborska Gora and Žumberak [14-17]. Their clasts are regularly found as constituents in the overlying Neogene carbonate breccias. Pebbles of these rocks are also significantly incorporated in Plio-Quaternary alluvial deposits of the Sava Rive [18]. Similar Middle Triassic rocks were also described as the Neogene basement rocks in the Papuk Mt. [19], where Middle Triassic limestones and dolomites predominate.

Several lithofacies of Triassic dolomites were described in the Medvednica Mt. Dark-grey dolomite, often intersected with secondary tectonic cracks and veins (Figure 2.2a) filled with carbonate cements and matrix, prevail among carbonate lithotypes. This dolomite is heavily weathered, often cut up in small pieces, and grind up to the sand grain size. In a microscale, it shows fine-grained to medium-grained hipidiotopic dolomite texture (Figure 2.2b). It is often accompanied with dolomite breccias of different types and origin. These rocks show various types and significant volumes of secondary porosity, mainly of diagenetic or tectonic origin, as well as the combination of both $[15,17]$. 


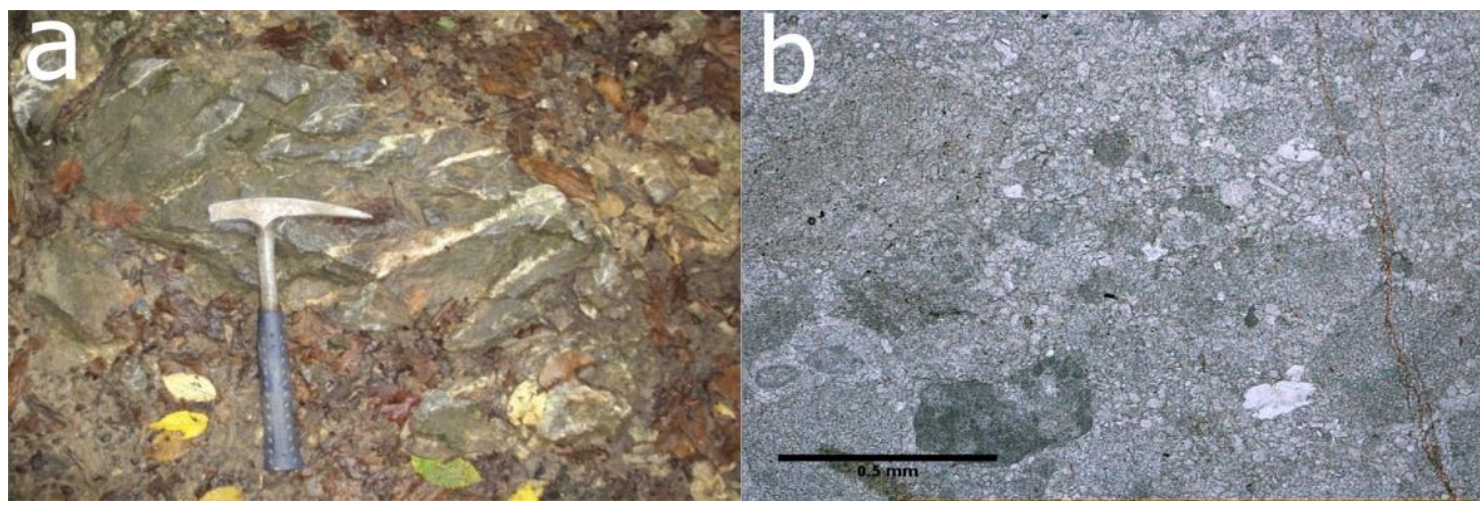

Figure 2.2: a - left Outcrop with dark grey dolomite in the Medvednica Mt.; b - right Microphotograph of brecciated dark grey dolomite (The width of the microphotograph is $1.7 \mathrm{~mm}$ ).

The light crystalline dolomite is almost equally represented in the outcrops and quarries (Figure 2.3a), having hipidiotopic to xenotopic macrocrystalline texture, often accompanied with brecciated dolomite fabric (Figure 2.3b). These are, again, rocks with the significant secondary porosity of the diagenetic origin in light crystalline dolomites, further enhanced due to tectonics in dolomite breccias. All these carbonate rocks described in Medvednica Mt. are intensively weathered and karstified at the surface outcrops, and they represent significant and valuable volumes for karst aquifers development. This is also determined for similar Triassic carbonate rocks from the Papuk Mt. [19].

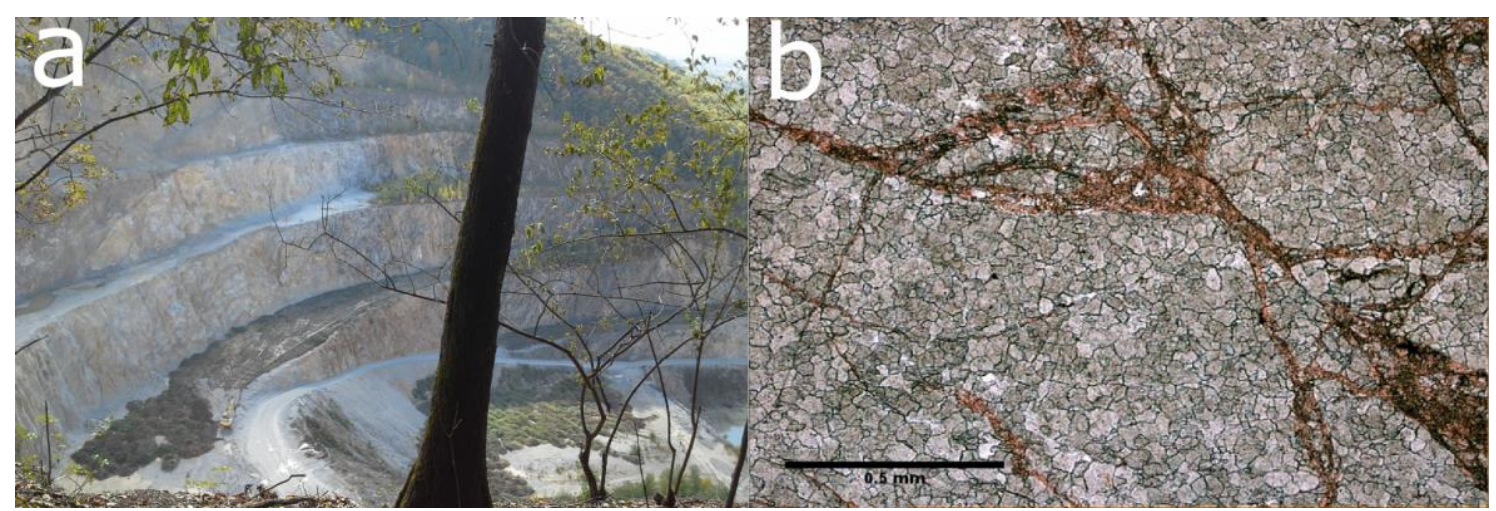

Figure 2.3: a - left Outcrop with light grey dolomite in Medvednica Mt. (Ivanec Quarry); b - right Microphotograph of brecciated light grey dolomite (The width of the microphotograph is $1.7 \mathrm{~mm}$ ).

Low-grade metamorphic rocks of the greenschists metamorphic facies from the central part of the Medvednica Mt. [10] represent an analog for similar metamorphic rocks in the pre-Neogene basement of the CPBS. These rocks are the products of low-grade metamorphism, affecting in Mesozoic older sedimentary and volcano-sedimentary successions [14,20,21]. Their appearance at outcrops (Figure 2.4a), as well as in the hand samples (Figure 2.4b) shows compact, lepidoblastic and nematoblastic schist structures of these rocks. 


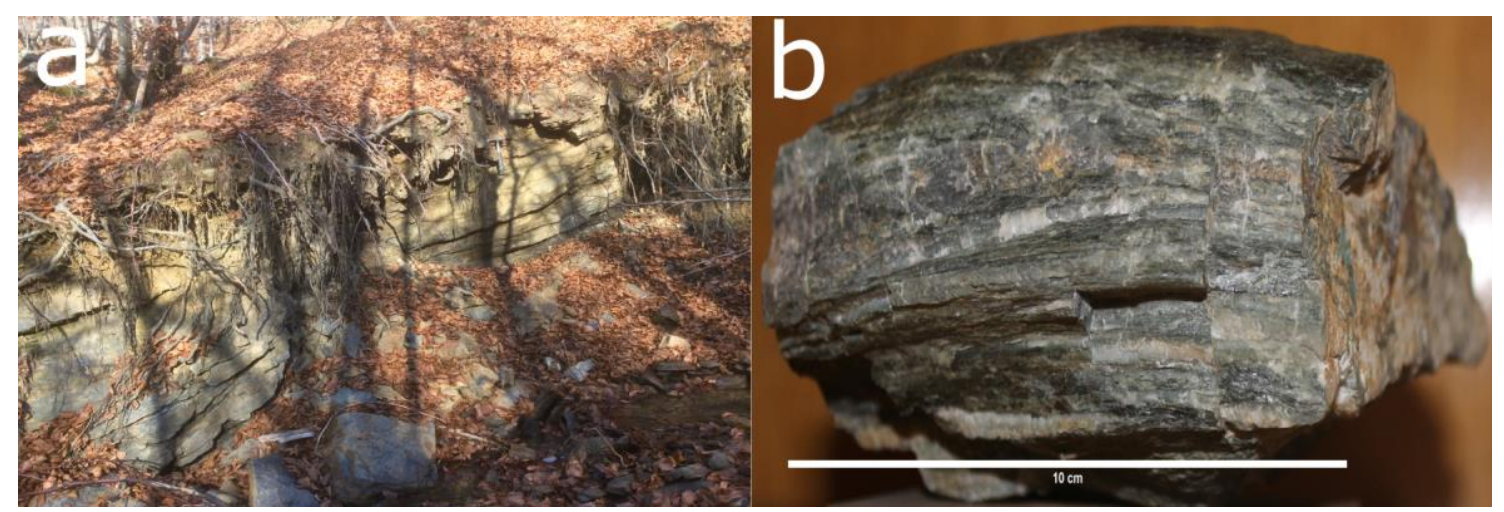

Figure 2.4: a - left Outcrop with the greenschists in the Medvednica Mt.; b - right Hand sample of the greenschists from the Medvednica Mt.

Physical properties of greenschist often show anisotropy due to described structure, and their porosity is lower than in observed sedimentary carbonate rocks, unless the rocks are later tectonised and secondary porosity of tectonic origin developed as cracks and fissures within the rocks.

Magmatic rocks occasionally intruded within the other pre-Neogene basement rocks of the CPBS. Recently, several types of granitoids from the pre-Neogene basement of the CPBS were reported from the deep wells in Eastern Croatia. These rocks were analysed and interpreted as shallow plutonic alkalifeldspar granites; hypabyssal monzodiorites-granodiorites; as well as monzogranites and leucogranites [22]. All these rocks are more-or-less compact, and they have grainy to porphyric structures with low porosities, unless they are later tectonised, similar as for previously described metamorphic rocks.

\section{Basic geological settings of the pre-Neogene basement rock in the Northern Croatia}

All rock types drilled and discovered in the Northern Croatia could be divided in two different groups. The first, younger includes Neogene and Quaternary deposits and the second the rocks in the pre-Neogene basement. They are also lithologically very distinctive. The Ng-Q sediments are clastics, and basement rocks carbonates (mostly Mesozoic) as well as magmatites and metamorphites (mostly Palaeozoic). The younger are better explored, but enough regional data is available for both groups. The Mz-Pz group has been marked as target for subsurface disposal of wasted nuclear fuels, i.e., radioactive waste because of: (a) depth, (b) compactness and hardness with lower porosity and permeability, (c) lower influence of neotectonic displacements, (b) they are not subdued to meteoric, but only connate waters.

The entire Northern Croatia is part of the Croatian part of the Pannonian Basin System (CPBS), shown on Figure 3.1, divided in the 4 large, regional depositional-tectonic structural units of the $2^{\text {nd }}$ order. Those are Mura, Drava, Sava and Slavonija-Srijem Depression. In the Sava Depression 2 regional units of the $3^{\text {rd }}$ order are located - the Karlovac and Požega Subdepression and in the Drava Depression - the Bjelovar Subdepression. The basement rocks are explored on the hills and mountains at margins (e.g., Trgovska gora) and in central parts (Medvednica, Moslavačka gora, Psunj, Papuk, Požeška gora). 


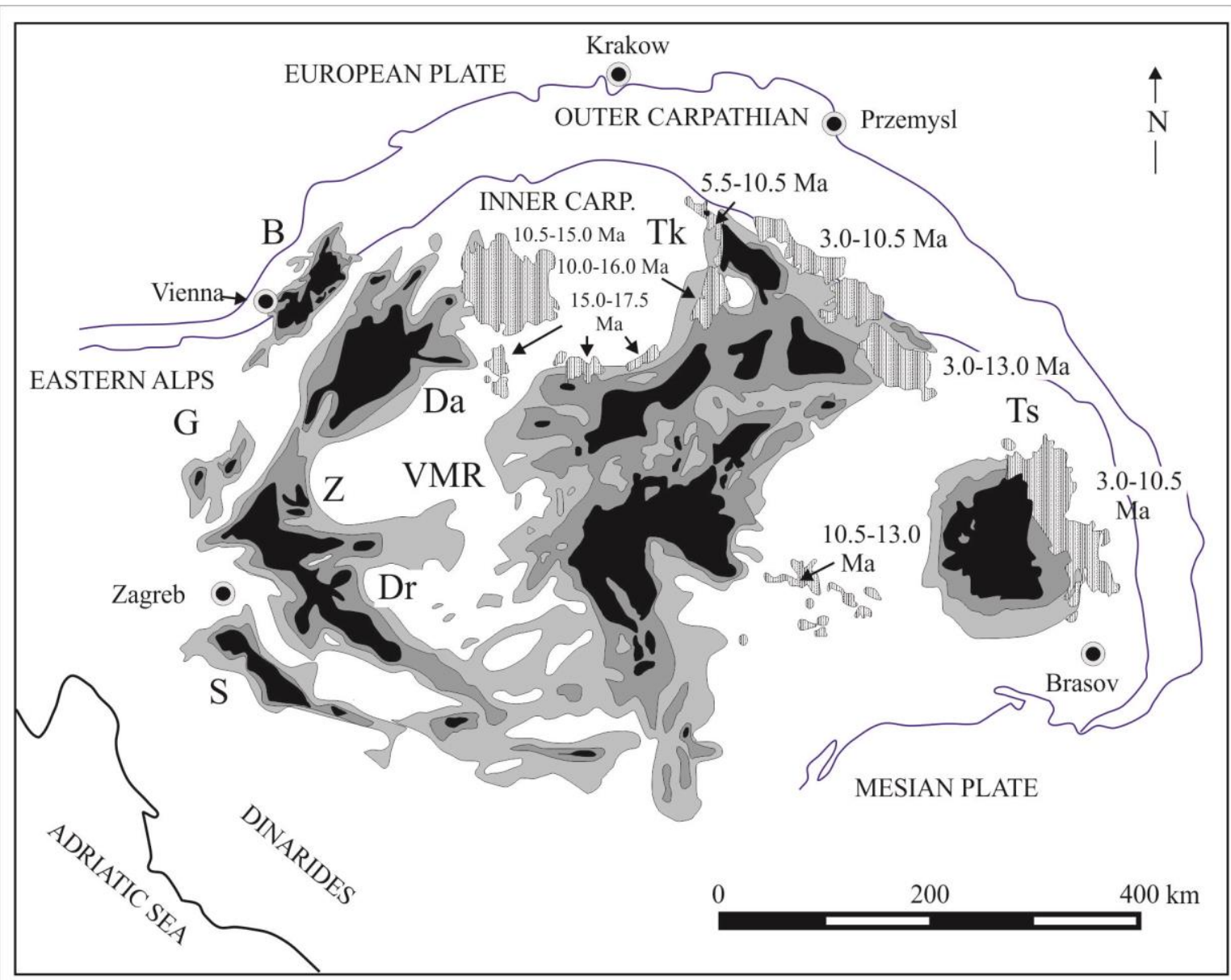

\section{LEGEND:}
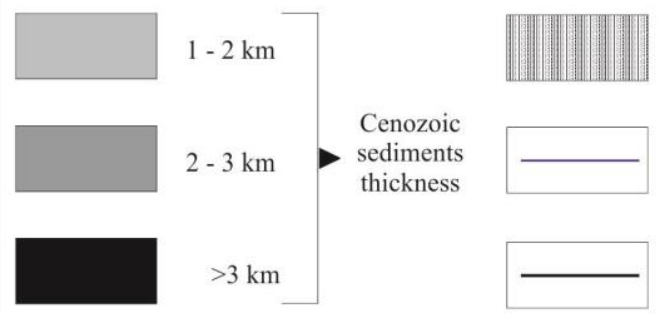

volcanic rocks of Upper
Cenozoic with age in Ma
Pannonian Basin System
borders
coastline

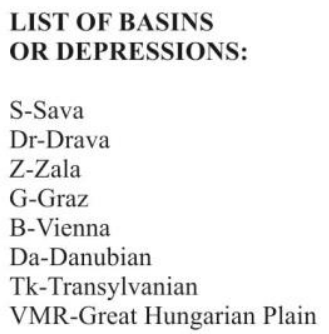

Figure 3.1. Location of the Croatian part inside the Pannonian Basin System / CPBS in the PBS [1].

The CPBS (e.g., [1,23-28]) has been created at the margin of the PBS, which has been reflected in some depositional and tectonical specific features. The entire CPBS is created along the several regional transcurrent faults. The first lake environments were created in Lower Miocene. In the Lower Badenian (16.4-15.0 Ma) the $1^{\text {st }}$ marine transgression of the Central Paratethys covered the Northern Croatia, with dominant alluvial fans, sources in siliciclastic basement and Corallinaceae reefs and fast subsiding ( $1^{\text {st }}$ transtensional phase). During Middle and Upper Badenian (15.0-13.0 Ma) tectonics was weak and fine-grained clastics and carbonates were deposited. The period ended with the $2^{\text {nd }}$ flooding of the Paratethys.

It was followed with the $1^{\text {st }}$ transpressional phase from Sarmatian to the end of the Lower Pannonian (13.0-9.3 Ma), when gradually large the Pannonian Lake (brackish to fresh-water) was created. It was followed by the $2^{\text {nd }}$ transtensional stage lasted through Upper Pannonian (9.3-7.1 Ma) and Lower Pontian (7.1-6.3 Ma). The monotonous, thick marls and sandstones sequences were deposited, firstly in the Pannonian Lake, later in local Sava and Drava lakes. Sandstones originated from Eastern Alps detritus, transported with turbidites and resedimented on tectonic ramps. Marls are typically of lacustrine origin. 
The last is the $2^{\text {nd }}$ transpressional phase, starting in the Upper Pontian (6.3-5.6 Ma). The lacustrine environments are reduced on the Slavonija Lake, eventually closed in Pliocene (5.6-2.6 Ma). The Quaternary (2.6-rec. Ma) is a completely continental environment. During the entire Upper Cainozoic, especially during transpression, older structural highs and mountains (e.g., Medvednica, Papuk, Psunj) had been uplifted and during the last 2.5 Ma, Bilogora [29]. It resulted in significant thickness of the Ng-Q sediments with more than $7000 \mathrm{~m}$ in the Drava, and more than $5000 \mathrm{~m}$ in the Sava Depression. Depositional evolution and lithology of the CPBS are clearly visible in regional lithostratigraphy and can be easily correlated and compared in all depressions (Figures 3.2 and 3.3).

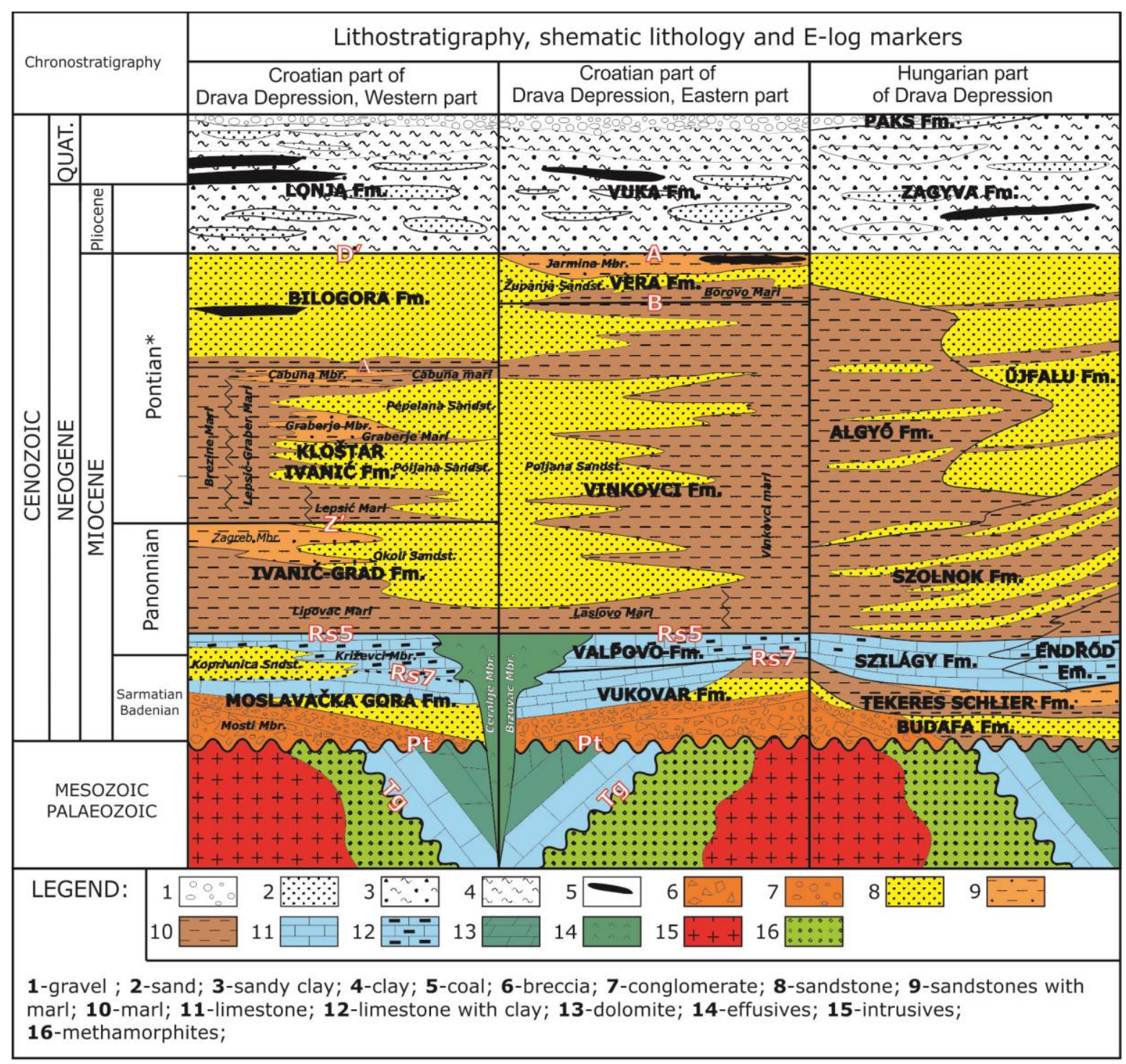

Figure 3.2. Schematic lithostratigraphic review through the Drava Depression [30]. 


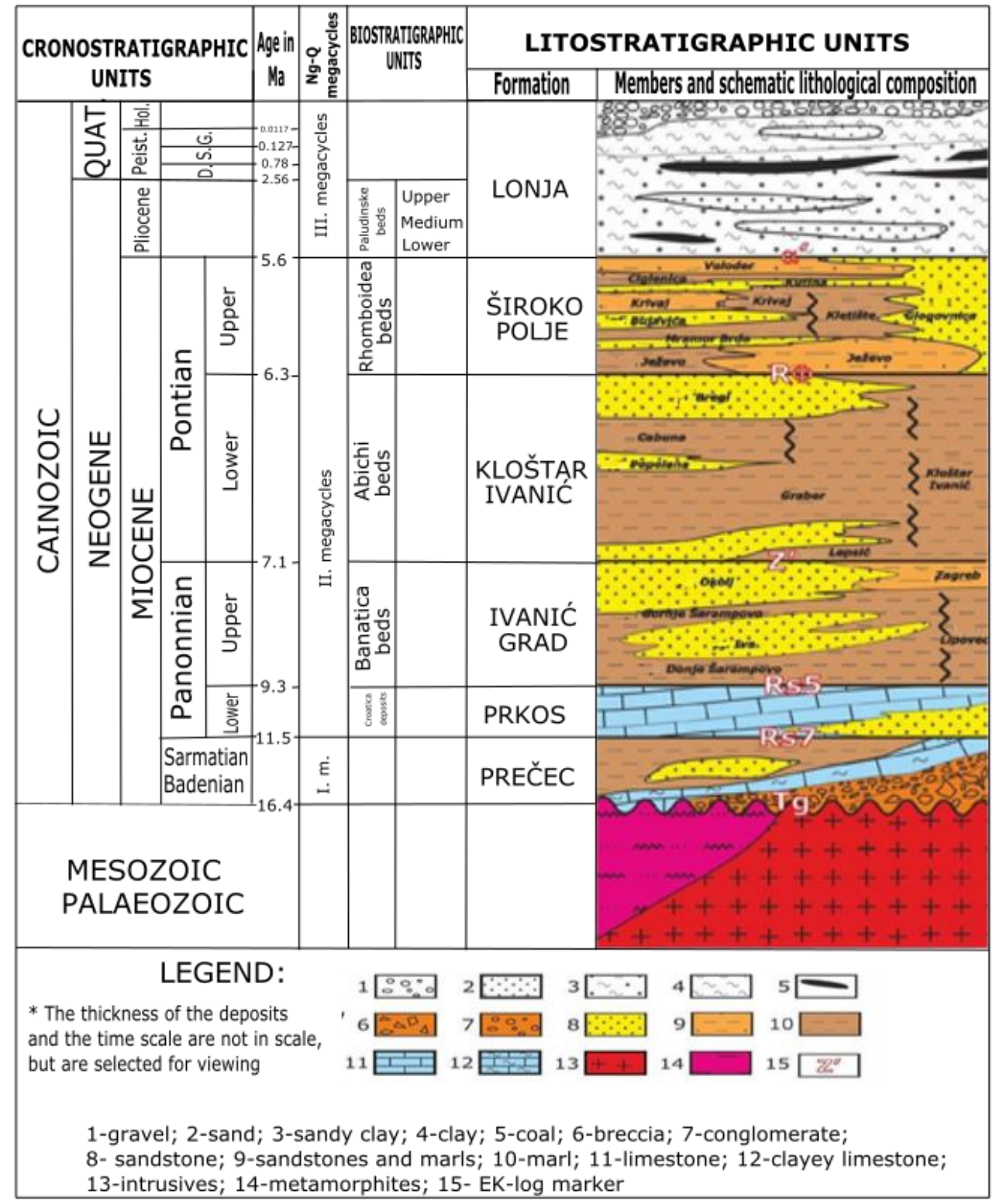

Figure 3.3. Schematic lithostratigraphic review through the Drava Depression [8]

The long-lasting deposition and tectonics resulted on numerous structures and fault zones. The major ones are mapped from the basement up to surface, other are local and shorter. However, along the major fault systems throws could reach several hundred meters (Table 3.1, locations are given at Figure 3.4), as it could be verified on examples taken from regional structural map of the Bjelovar Subdepression [31]. 
Table 3.1. Absolute vertical fault throws (in meters) along the main fault zone in the Bjelovar Subdepression

\begin{tabular}{|c|c|c|c|c|c|c|}
\hline & $\begin{array}{c}\text { Pre-Cenozoic - } \\
\text { Miocene } \\
(16-4 \mathrm{Ma}) \\
\end{array}$ & $\begin{array}{c}\text { Sarmatian - Early } \\
\text { Pannonian } \\
(11.5 \mathrm{Ma}) \\
\end{array}$ & $\begin{array}{c}\text { Early - Late } \\
\text { Pannonian } \\
(9.3 \mathrm{Ma}) \\
\end{array}$ & $\begin{array}{c}\text { Late Pannonian - } \\
\text { Early Pontian } \\
(7.1 \mathrm{Ma}) \\
\end{array}$ & $\begin{array}{c}\text { Early - Late } \\
\text { Pontian } \\
(6.3 \mathrm{Ma}) \\
\end{array}$ & $\begin{array}{c}\text { Late Pontian - } \\
\text { Pliocene } \\
(5.6 \mathrm{Ma}) \\
\end{array}$ \\
\hline (1) Primary normal & 300 & 100 & $100-200$ & 100 & 100 & 50 \\
\hline (2) Secondary normal & 100 & 100 & 100 & - & - & - \\
\hline (3) Western & 150 & 100 & 100 & 50 & 50 & 50 \\
\hline (4) Štefanje & 50 & 50 & 50 & 50 & 50 & 50 \\
\hline \multicolumn{7}{|c|}{ Diagonal Faults (WNW-ESE) } \\
\hline (7) Bilogora & 200 & 100 & $100-200$ & 100 & 50 & 100 \\
\hline (8) Šandrovac-Ciglena & 50 & 100 & $100-200$ & 50 & 50 & 50 \\
\hline (9) Primary reverse & 200 & 100 & 100 & 100 & 100 & 50 \\
\hline (10) Secondary reverse & 200 & 100 & $50-100$ & 100 & - & - \\
\hline
\end{tabular}

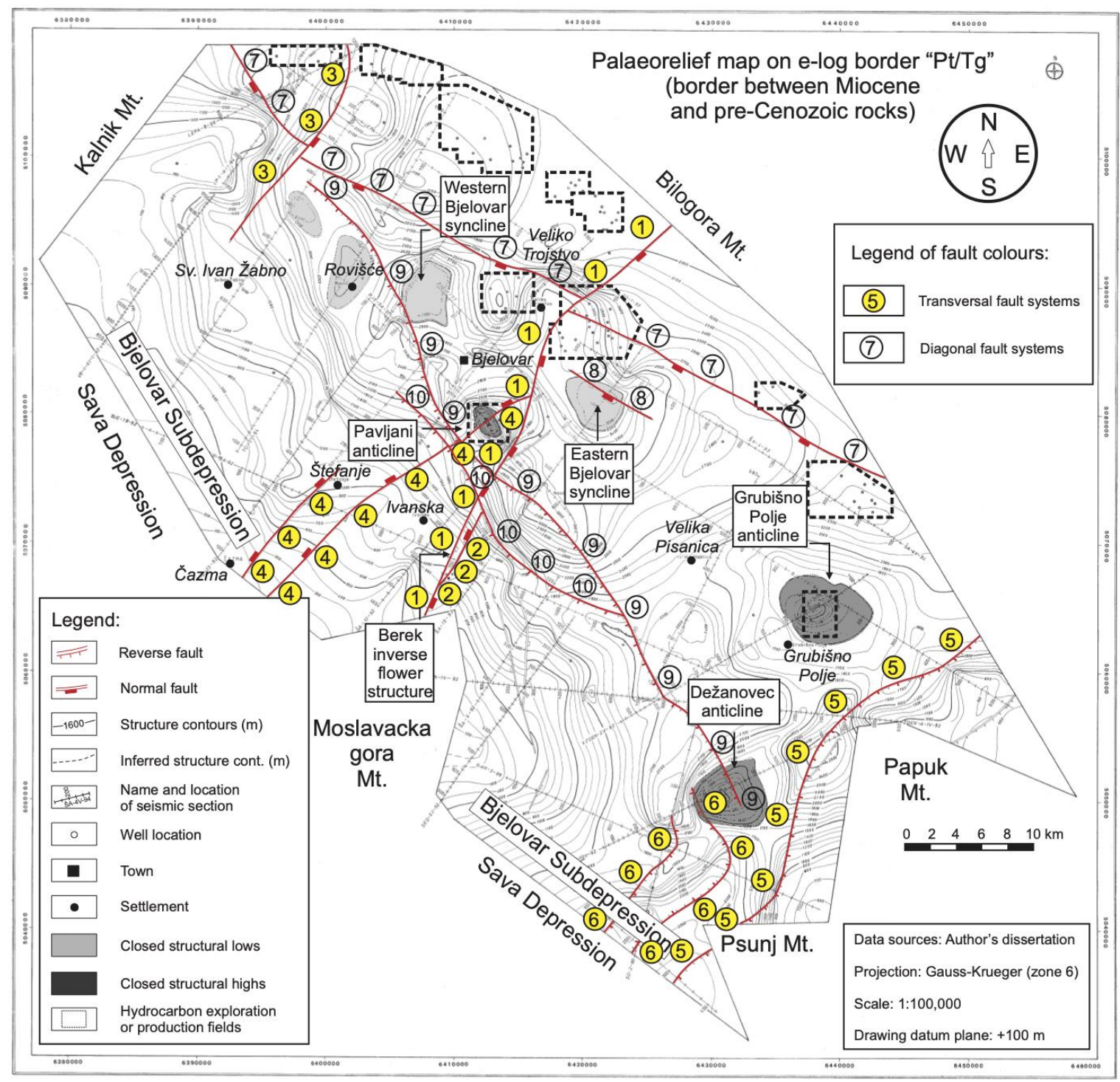

Figure 3.4. The main fault zones in the Bjelovar Subdepression shown on palaeorelief map of the Neogene basement [31].

\section{Lithology and petrophysics of the pre-Neogene basement rock in the Northern Croatia}


As mentioned, there are two lithological types of the Neogene basement: magmatics and metamorphics, dominantly Palaeozoic, and carbonates, mostly Mesozoic.

Magmatics and metamorphites are, in practice, name as "basement rocks" ("temeljno gorje"). Such name can also be considered as an informal lithostratigraphic unit of group rang. Palaeozoic is often composed of granites and gabbro intrusions, and, by intrusion, cracked and altered, metamorphized rocks. Metamorphites include amphibolitic facies with different schists and gneisses.

Also, there are subdued to several orogeny cycles and displaced from their locations numerous times. However, deep data can be correlated with the same lithotypes collected from outcrops on mountains and hills in the CPBS. Dominantly, those rocks are Palaeozoic, but some are described as Mesozoic. For example, [32] stated that ofiolites in the SW part of the PBS continuously created both in Palaeozoic and Mesozoic. Later, [33] described gabbro and serpentinite on NW Majevica and Trebovac as Upper Cretaceous. The most of schists are formed during intrusions of granite magma, caused by contact metamorphosis, what resulted in quartz-mica and quartz-mica-chlorite schists. Mineral paragenesis showed on greenschist facies. Well data are extremely significant for the determination of petrophysical values, particularly in the weathering zone that is almost always developed in the topmost part, also characterized with secondary porosity. It also made it possible to accumulate hydrocarbons in such zone, what is confirmed with several smaller discovered reservoirs where weathered basement makes one hydrodynamic zone (reservoir) with the oldest Badenian breccia (like in the Galovac-Pavljani, Letičani, Grubišno polje fields). There is also one huge discovery in such environments of gas-condensate reservoirs in anticlinorium Molve-Kalinovac-Stari Gradac. Such weathering, mostly happened during Palaeogene, and could develop from several meters to several dozens of meters from the basement top.

The next rock group of carbonate rocks has been named in practice as "Tertiary basement" ("podloga tercijara") and can also be considered as an informal lithostratigraphic group. Those are different limestones and dolomites, often cataclysed and weathered in breccia and conglomerates, especially in the youngest part. Such rocks are also drilled in the deepest parts of the CPBS, like in the Drava Depression in the wells Vir-3 (where effusives are syngenetic with carbonates) and Or-1 (Figure 4.1) where dolomites are detected at $-4740 \mathrm{~m}$ 


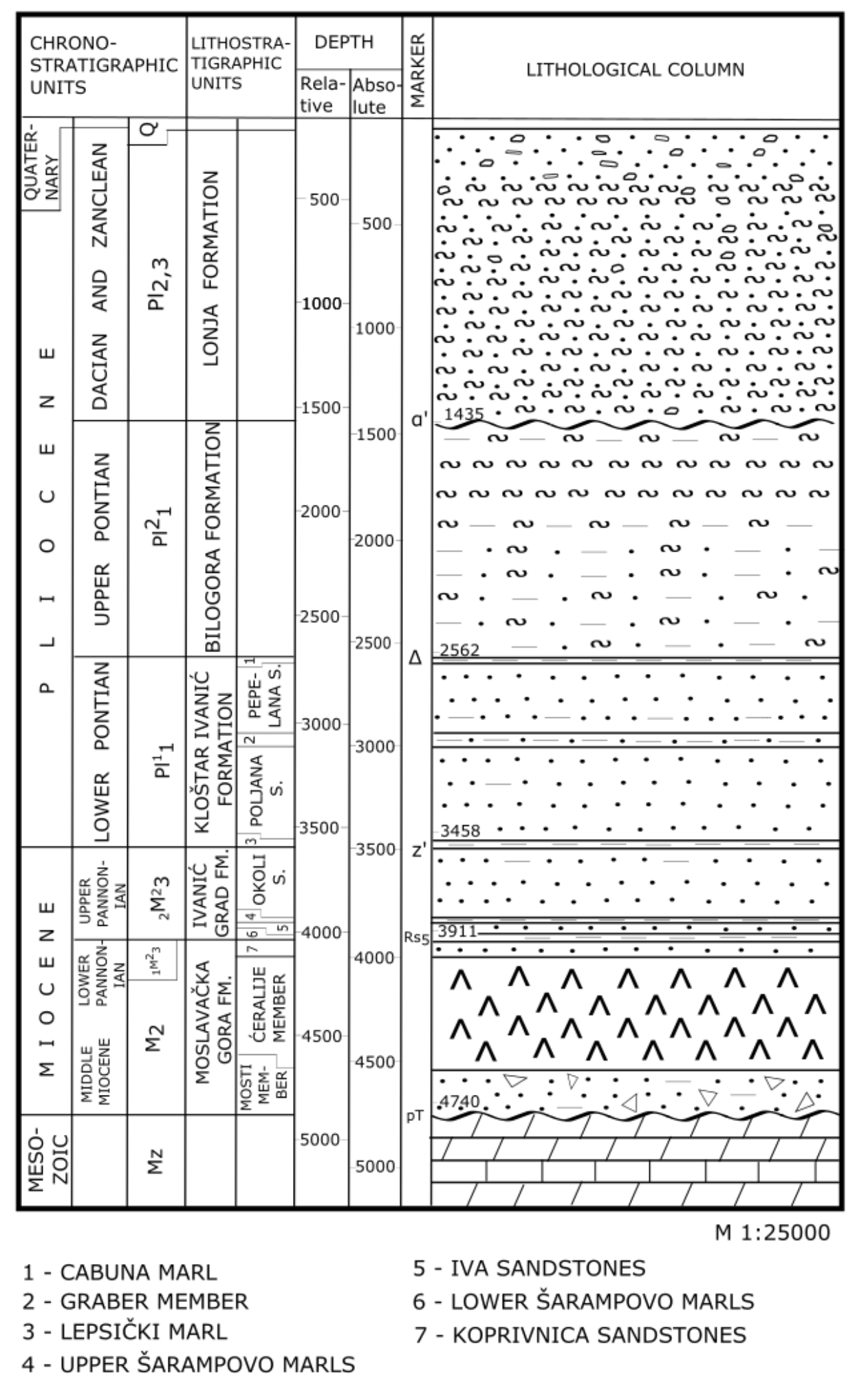

Figure 4.1. Lithostratigraphic section in the well Or-1 (original redrawn from [34]).

Petrophysical values of the basement rocks are mostly very rare, when compared with younger rocks in the CPBS. However, the dataset was enough comprehensive to get regional insight in interval values of porosity and permeability, as critical variables for any estimation of sealing properties, which can be calculated from cores or logs. Such values were generally low, lower in the magmaticmetamorphic than carbonate basement (which has been subdued much stronger to dissolving and cataclising). In basement, for example, in the Bjelovar Subdepression porosity varies between 0.9 and $4.1 \%$ in different schists, quartzite sandstones and gabbro. The maximal vertical permeability is, in 
VT-1 well, $0.24 \times 10^{-3} \mu \mathrm{m}^{2}$. The basement rocks, as well as hydrocarbon reservoirs in them, can be easily recognised on e-logs (Figure 4.2).

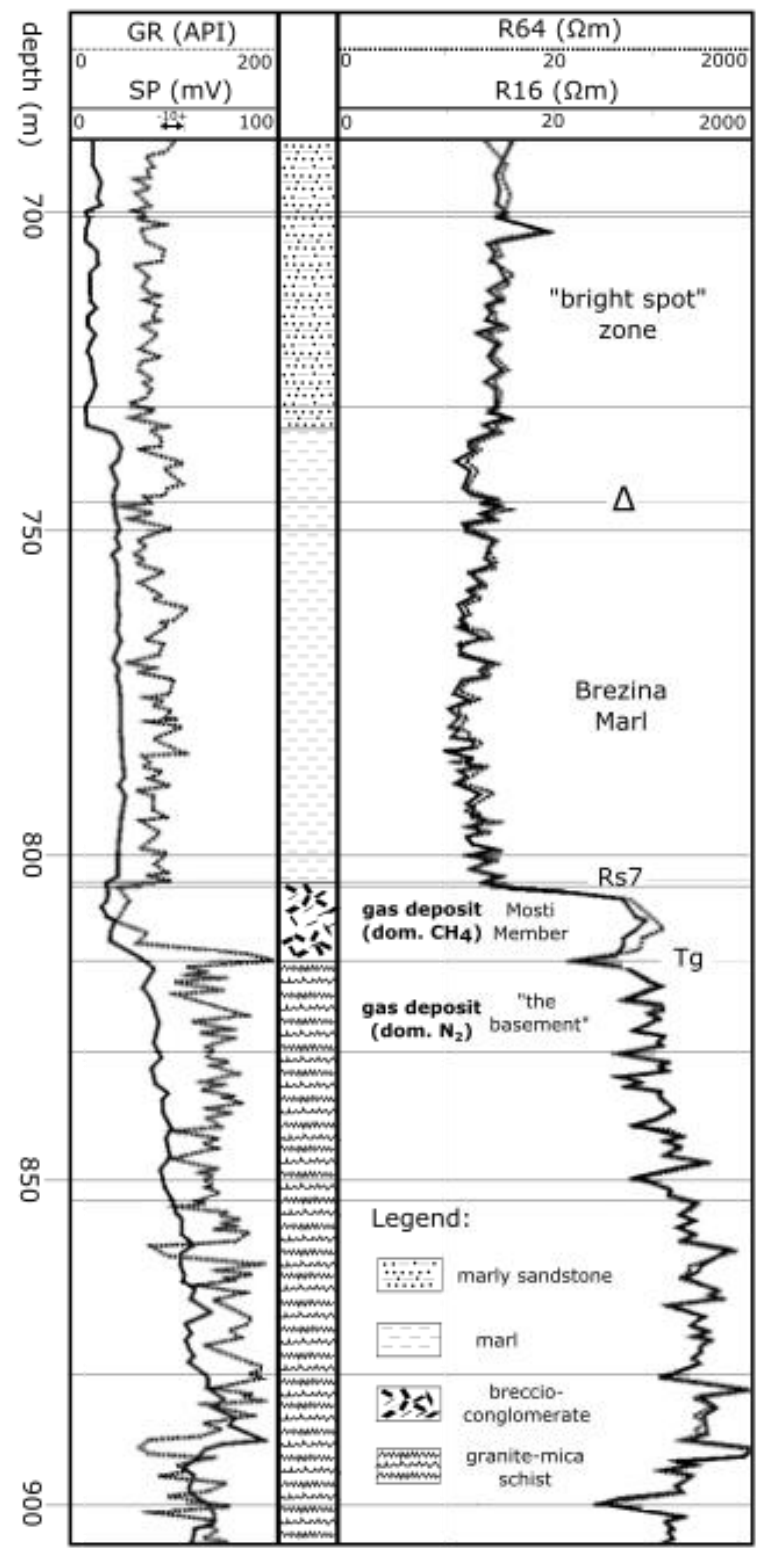

Figure 4.2. Conventional log in the Palaeozoic basement rocks, well Gr-1z, eastern Bjelovar Subdepression (original redrawn from $[1,35]$ ).

In Mesozoic carbonates, the petrophysical values were generally slightly higher, e.g., $2 \%$, with both permeabilities mostly less than $0.1 \times 10^{-3} \mu \mathrm{m}^{2}$ (example of Dež-1 well, Bjelovar Subdepression).

There were also interesting data about basement saturated water salinity. As average for the Drava depression [36] published $18 \mathrm{~g} / \mathrm{l} \mathrm{NaCl}$ for magmatites and metamorphites and $15 \mathrm{~g} / \mathrm{l}$ for carbonates. But locally, values can significantly vary [37], from 3.24 (Gr-1z) to $15.34 \mathrm{~g} / \mathrm{l}(\mathrm{Pav}-1)$ for magmatites/metamorphites, and from 9.9 (VC-1) to 23.29 (Ptk-1) g/l. The lower values in magmatites/metamorphites are the probable result of mixing with waters from younger formations, and higher in carbonates on longer inactivity of aquifer and consequently stronger dissolving.

The is also one very famous structure in the CPBS where Palaeozoic and Mesozoic rocks can be simultaneously studied based on numerous data from deep wells, seismic and logs. That is the Molve Structure, located in the central Drava Depression (Figure 4.3). 


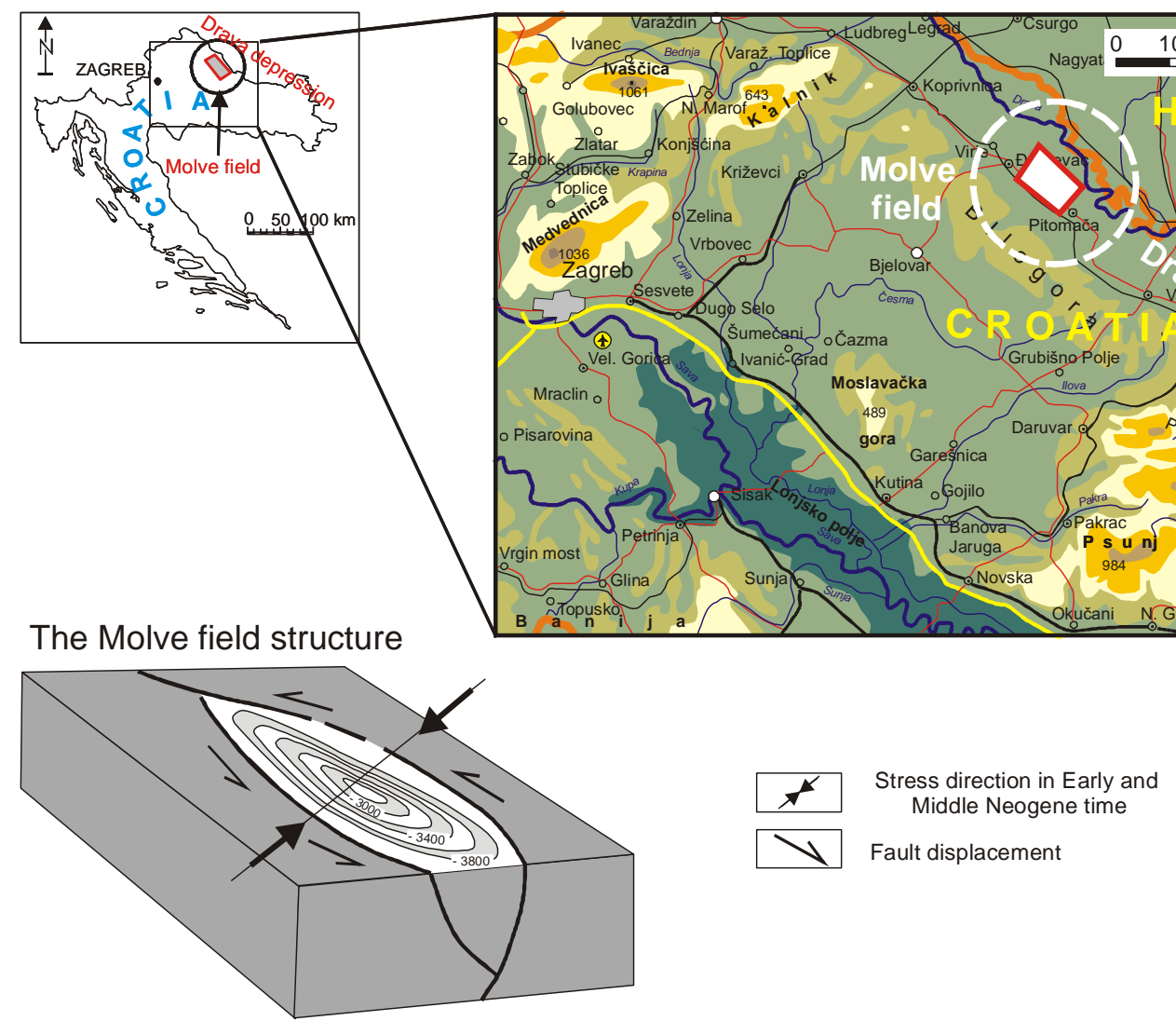

Figure 4.3. Geographical location of the Molve Structure [38].

The structure is particularly interesting because hydrocarbon reservoir included even four different lithofacies, from Palaeozoic to Badenian, each with its own petrophysical properties, but still representing single hydrodynamic unit. Those four lithofacies (e.g., [38]), from the youngest to oldest, are:

- Lithofacies I: informally Grainstone; Middle (Lower?) Miocene; Lithothamnium limestones, biocalcarenites and biocalcrudites (porosity $20 \%$ ) and biomicrites (5\%).

- Lithofacies II: informally Dolomites (Middle and Upper Triassic); early to late diagenetic dolomites, oolites dolomites, limestones, breccia, conglomerates.

- Lithofacies III: informally Quartzites (Lower Triassic); metasandstones and quartzites, sporadically dolomites, dolomitic breccia, slates.

- Lithofacies IV: informally Diaphorites (pre-Devonian, Devonian); different magmatites and metamorphites, prevail cataclised granite and amphibolitic schists.

Analysing porosity variations through those four lithofacies, it could easily be observed a regular decreasing of values along depth and age of rocks (Figure 4.4). It goes from $20 \%$ in Badenian breccia, to less than $2 \%$ in Palaeozoic diaphtorite rocks. However, some samples from diaphtorite rocks develop secondary porosity around $20 \%$, what is a clear indication of strong weathering zone in the topmost part of the basement. 


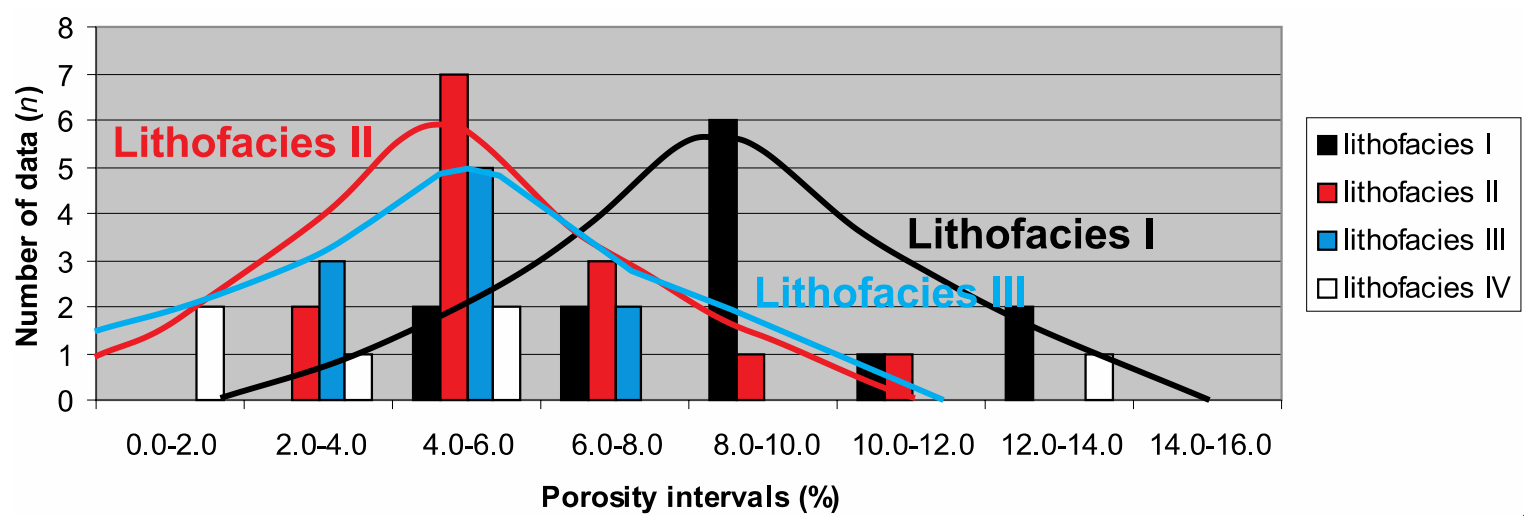

Figure 4.4. Histograms of interval porosity values in the lithofacies of the Molve structure. The lithofacies I-III could be approximated by Gaussian distribution [38].

\section{Proposal and discussion of a modified PoS methodology for radioactive waste disposal in pre- Neogene basement of the Northern Croatia}

Every modelling in the subsurface exploration can comprise two main routines. Static geological modelling and dynamic engineering simulation. Both can be done simultaneously or only static model alone during early, exploration phase. These two approaches are often interconnected in one general integrated model. Completely geological model includes numerous analytical methods (stratigraphic, structural, tectonics studies, petrophysical and geochemical variables analyses, creation of maps). In a later stage, fluid migration parameters could be also collected. All or the most of these data need to be collected during modelling of deep borehole disposal (DBD) radioactive waste programme.

For any variable, the most important property is spatial continuity, which directly is connected with data quantity and clustering. The geological variables (e.g., porosity, permeability, thickness) have spatial continuity, that could be expressed via autocorrelation function (such as a variogram). They are also regionalized variables distributed in the space with known general statistics, but also with uncertainty interval. That has to been taken into consideration when they are selected in the modified PoS intended for DBD of high-radioactive waste (HRW). Previously, two assumptions are set for selection of favourable geological units for HRW disposal: (1) promising structures are selected on structural and palaeostructural maps; (2) promising lithostratigraphic units are selected in basement with low petrophysical values.

5.1. Connections between categories in classical and modified PoS models (hydrocarbon vs. DBD critical variables).

The PoS table used for hydrocarbon reservoir probabilities is largely modified, using only those two assumptions. The classical principle, based for example on the workflow published, e.g., in [39] and [40] studies, was carefully re-designed for each of the four categories defined in a typical hydrocarbon system. Such modification had been done in the past, but in significantly lower extensions and for problems still defined in hydrocarbon systems. Example of such PoS systems, applied in the CPBS, could be find in [41,42], and also are shown on Figure 1.1. However, the basement rocks in the Northern Croatia subsurface are not still extensively explored, so the any PoS methodology intended to evaluate that lithology cannot incorporate detailed list of numerous geological events and probabilities as it was possible to create for Neogene hydrocarbons systems in the Northern Croatia. So, the most variables in categories of hydrocarbon systems must be replace or omitted.

Category "Source rocks-maturity-migration" - the existence of source rocks is not important for the assessment of basement rocks, especially they cannot contain source facies at all. But the temperature 
variable, as one of crucial for organic matter maturity, is mportant for long-term preservation of any artificial inputs in basement rocks in "original" or intact state. So, the variable "temperature" is translated in the modified PoS as new category.

Category "Trap-isolator rocks-time" - the type and volume of trap are not important as such, due to solid waste to be disposed in the rock systems where structural closure is not important as well as time for migration. The sealing properties are only and the most important variable. That has to fit condition that any migration of radioactive nuclides must be stopped and practically slowed to zero regarding geological time scale. So, in this particular modification, the isolator properties (natural and artificial) need to be highlighted as category.

Category "Reservoir-porosity-permeability" - Reservoir rocks are one of the most critical parameters. In hydrocarbon system it is the most favourable, in the DBD the most disadvantage variable. Any type of porosity (either primary or secondary) and permeability are not desired in the DBD programme and are considered as critical variable for new category. The fault zones, as the second critical variable, also decrease the permeability of DBD volume for HRW, in particular such fault zones where cementation has not happened or finished.

Category "Preservation-quality-producing" - is almost entirely very specific for hydrocarbon systems. Preservation, production and quality of hydrocarbons are not connected in any way with the HRW, except as indicators of subsurface fluid activity, flushing, degradation or ionic exchanges. The majority of such events are result of regional stress values and history, salinity difference and stratifications, and regional hydrological conductivities and geo-pressure. So, the aquifers' properties would be presented as category, connected with numerous measurements from the previous ones.

Just like hydrocarbon systems, the deep borehole disposal (DBD) of radioactive waste is based mostly on measurements from deep wells. Improvements in drilling technologies in the past revived the DBD for disposal of high-radioactive waste (HRW), like spent fuel and plutonium, instead of placement in mines underground caverns and mines at depths 500-800 m (e.g. [43]). The largediameter cased boreholes can be used at 4-6 km depths, to safely disposed the HRW into the granitic basement, i.e. upper part of the continental crust. The radioactive waste is disposed at lower and sealing in the upper part of such wells [43]. The granite is almost always considered as typical ideal lithology for HRW disposal all over the world. For example, [44] described The Beishan area (NW China, Gansu Province) as the most suitable country area for HLW repository because of its favourable socio-economical and natural conditions, which included 8 ( 3 the most) favourable granite intrusions, where total crust thickness is $47-50 \mathrm{~km}$ and no earthquakes with Ms $>4.75$ were recorded. The hydraulic conductivity ranges between $6.6 \times 10^{-10} \mathrm{~m} / \mathrm{s}$ and $3.9 \times 10^{-14} \mathrm{~m} / \mathrm{s}$ suggesting that most extremely low permeability. Considering also the moderate in-situ stress (4.54-12.77 MPa) the described granite could be a location for the permanent disposal of HLW. However, such sites are sensitive on the complex stress fields, which could initiate earthquakes. Their triggering is related to the changes in stress fields [45]. Consequently, it is necessary to make a map of earthquake distribution in analysed area and point out all of them with some "critical" magnitude (e.g., Ms $>5$ or 6) happened in the past and recorded in historical data.

\subsection{The new categories and critical variables}

The categories and parameters for the modified PoS that could be applied for radioactive waste disposal (critical variables are included) in the Northern Croatia are shown in Table 5.1. All probabilities can range between 0.0 and 1.0. Value 1.0 is added if all subcategory criteria are completely satisfied at the most favourable level. Oppositely, if none of such criteria is matched, the value is 0.05 (if measurements are missing or 0.0 (if non-existence is proven). Single category 0.0 value makes all further calculation unnecessary.

Table 5.1: Categories and variables selected for the modified PoS to potentially be applied for radioactive waste disposal in the Northern Croatia 


\begin{tabular}{|c|c|c|}
\hline & $\begin{array}{l}\text { Probability of the crucial } \\
\text { geological or engineering } \\
\text { events in the category }(0-1)\end{array}$ & Probability for category \\
\hline $\begin{array}{l}\text { (A) temperature } \\
\text { a1. The present-day temperature in basement rocks } \\
\text { are considered as a long-term value. } \\
\text { a2. Quaternary volcanism is not observed. } \\
\text { a3. The palaeothermal gradient is known at least for } \\
\text { the last } 100 \mathrm{Ky} \text {. } \\
\text { a4. Heat flux }<75 \mathrm{~mW} / \mathrm{m}^{2}\end{array}$ & $a 1 \times a 2 \times a 3 \times a 4=$ & $A$ \\
\hline $\begin{array}{l}\text { (B) isolator properties of rock and sealings } \\
\text { b1. Lithological isolator properties need to be proven } \\
\text { all around the disposal volume. } \\
\text { b2. Granite is favourable, magmatic and } \\
\text { metamorphic are necessary condition. } \\
\text { b3. The sedimentary sequence in the top of } \\
\text { granite/magmatics is rich in clayey and fine- } \\
\text { grained rocks (claystones, marls...). } \\
\text { b4. If artificial sealing of the borehole displacement } \\
\text { zone is performed, its quality must be proven. }\end{array}$ & $b 1 \times b 2 \times b 3 \times b 4=$ & $B$ \\
\hline $\begin{array}{l}\text { (C) low petrophysical values }+ \text { fault zone(s) } \\
\text { inactivity } \\
\text { c1. Petrophysical isolator properties }\left(<2 \%,<10^{-15} \mathrm{~m}^{2}\right) \\
\text { needs to be proven all around. } \\
\text { c2. Fault zone(s), distant } 2-10 \mathrm{~km} \text {, must be inactive or } \\
\text { with throw less than } 50 \mathrm{~m} \text { in Quaternary. } \\
\text { c3. Regional fault zones must be distant more than } 2 \\
\text { km from disposal, and closest fault zone }(\mathrm{s}) \text { must } \\
\text { be cemented. } \\
\text { c4. Depth of HRW disposal has to be more than } 3 \mathrm{~km} \text {. }\end{array}$ & $c 1 \times c 2 \times c 3 \times c 4=$ & C \\
\hline $\begin{array}{l}\text { (D) subsurface fluids and aquifers } \\
\text { d1. Subsurface fluids and aquifers must be } \\
\text { regionally still, i.e., inactive. } \\
\text { d2. The deep saline aquifers are favourable. } \\
\text { d3. Small weathering regional zones in the } \\
\text { basement top as favourable. }\end{array}$ & $d 1 \times d 2 \times d 3=$ & $D$ \\
\hline STRUCTURE PROBABILITY $(E=A \times B \times C \times D)$ & & $E$ \\
\hline
\end{tabular}

A. Temperature. As one of the critical variables, temperature can degrade the stability of any metal or concrete container-based protection during a long-time interval $\left(10^{2}-10^{4}\right.$ years). Cumulative temperatures in the disposal volume could be results of several sources. The strongest is heat flow or geothermal gradient, the second is heat released from radioactive decay and the third could be artificially induced energy released from heaters to melt and recrystalised the rock where container are disposed.

Also, sealing properties depends on temperature. For example, [46] proposed using of highdensity support matrix (HDSM) for sealing of waste that generate, during decay, temperatures greater than approx. $185^{\circ} \mathrm{C}$ in the annulus (volume between disposed package and borehole walls). If the basement rock temperatures could be expected 80-130 ${ }^{\circ} \mathrm{C}$ [43] it is obvious that decay will generate additional heat, especially if highly radioactive fuels had not undergone process of cooling. The HDSM includes lead-based, fine-grained, alloy that is delivered after each waste package [46], filling all pores around such containers, in uncemented zone, i.e. between casing and walls.

The strongest natural influence on subsurface temperate comes from the geothermal gradient, i.e. geothermal heat flux, regional as well as local. In Table 5.2 is proposed heat flux $<75 \mathrm{~mW} \mathrm{x} \mathrm{m}{ }^{2}$ as upper marginal allowed value for the DBD. It is approx. like the regional mean value calculated for the CPBS, i.e. $76 \mathrm{~mW} / \mathrm{m}$, with geothermal gradient ranging $0.04-0.07^{\circ} \mathrm{C} / \mathrm{m}[47,48]$. 
Table 5.2. Examples of technical criteria for selecting a potential site for consideration, which would contribute to the safety case (taken from [49]; which modified it from [50], and DOE documents)

\begin{tabular}{|c|c|}
\hline Characteristics & Criteria \\
\hline Depth to crystalline basement & $<2 \mathrm{~km}$ \\
\hline Simple basement structure & $\begin{array}{l}\text { No known regional structures, major shear zones, major tectonic features } \\
\text { within } 50 \mathrm{~km}\end{array}$ \\
\hline Low seismic and tectonic activity & No Quaternary age volcanism or faulting within $10 \mathrm{~km}$ \\
\hline $\begin{array}{l}\text { Absent flow of fresh groundwater at } \\
\text { depth }\end{array}$ & $\begin{array}{l}\text { Absent significant topographic relief to drive deep recharge, old and highly } \\
\text { saline groundwater at depth }\end{array}$ \\
\hline Low geothermal heat flux preferred & $<75 \mathrm{~mW} / \mathrm{m}^{2}$ \\
\hline Sufficient area for well array & Design depedent \\
\hline Absent existing contamination & Absent surface or subsurface contamination at proposed site \\
\hline $\begin{array}{l}\text { Minimal disturbances from other surface } \\
\text { or subsurface uses }\end{array}$ & $\begin{array}{c}\text { Prefer sites with minor impacts, e.g., wastewater injection, oil and gas } \\
\text { activities, groundwater production, mining, and potential mineral resources } \\
\text { in bedrock }\end{array}$ \\
\hline
\end{tabular}

B. Isolator properties of rocks and sealings. Isolator rocks have to be located all around the disposed containers. [49] mentioned that DBD would be ideally at 3-5 km (or at least $>2 \mathrm{~km}$, where overlying argillaceous rocks could be benefit) in crystalline basement, reaching robust geological conditions that ask for minimal engineering support.

It needs to be evaluated both through basement lithologies as well as artificial sealings. Major uncertainties exist regarding the length of time that has to be guaranteed for disposed materials inactivity. The large influence has the quality of filling in case of drilling damage zone (or excavation damage zone, EDZ). Such zone, in granite, could be restricted to a few tens of centimetres [43]. According [51] EDZ thickness at mining enterprises during using of "conventional" technology varied between $0.3-1.4 \mathrm{~m}$

The EDZ, as by-pass, must be eliminated at least locally, i.e. in intervals just above disposal zone. One of the methods [46,52,53], similar to HDSM, could be applied at selected borehole interval where casing is removed, and finely grained, crushed granite (or any host rock) is backfilled. Such detritus is partially melted together with host rock using artificial electrical heating and left to slowly cooling and recrystalising into virtually original host rock, but without borehole damaging zone. The process is known as rock welding (e.g., [43]), where partial granite melting happened at $700-800{ }^{\circ} \mathrm{C}$, and then cooling, when about 550 oC finished recrystallisation. Eventually, natural and artificial sealing properties create stable the DBD volume.

C. Low petrophysical values + fault zone(s) inactivity. Based on experimental values from explored cores in the CPBS, the structure is basement often are characterised with porosities less than $2 \%$ and accompanied permeabilities (both in vertical and horizontal directions) less than $10^{-15} \mathrm{~m}^{2}$. In depths of few kilometres and in crystalline basement, such values could be expected. For examples, [43] stated for such rocks very low bulk hydraulic conductivities $\left(<=10^{-11} \mathrm{~m} / \mathrm{s}\right)$, even in fractured parts, and saline brines, which do not mix with meteoric ground water (rarely extend below 1-2 km), making density stratification. As results radioactive high-level wastes (HLW) cannot go far away from disposal place. Generally, crystalline rocks, especially in the stable mid-continent region, can be low permeable, where permeability of unfractured crystalline bedrock ranges from $10^{-16} \mathrm{~m}^{2}$ to $10^{-20} \mathrm{~m}^{2}$ [54]. Values decline with depth due to increasing confining pressures [49].

Fault zones must not cross disposal volumes and the closest ones must be inactive. The fault zone inactivity is hard to estimate because depends on numerous parameters like periodicity of fault activity, size of fault zone, length of fault, age of fault, is the fault zone cemented etc. In Table $\mathbf{5 . 2}$ is indicated that disposal place needs to be more than $10 \mathrm{~km}$ of active regional fault zone. However, as the CPBS is much narrow than mid-continent continental plateaus, and the deepest parts are connected with opening along main regional fault zones (Table 3.1, Figure 3.4), the $10 \mathrm{~km}$ limits would eliminate much of the deep basement as perspective for disposal. So, the $5 \mathrm{~km}$ distance between DBD well and main depressional fault zone would be adequate. The Quaternary volcanism as elimination parameter (Table 5.2) does not need to be applied in the CPBS (no present-day volcanic 
activity of shallow magma chambers) but fault activity does. The Quaternary low activity of regionally fault zones is necessary condition in selection of the DBD zone. The fault distance could be set at $5 \mathrm{~km}$ and low activity describe with Quaternary cumulative throw up to $50 \mathrm{~m}$.

D. Subsurface fluids and aquifers. They have to be still, regionally inactive, where the pressure gradient is gradually dispersed through rocks, mostly with geostatic normal pressure. "Safe and slow" flow would occur in nanosized pores found along the edges of crystals (e.g., [49]), not through developed fracture systems, when basement crystalline rocks may have much higher permeabilities with connected natural fractures. Nevertheless, there will be upward transport of radionuclides due to the presence of hot waste, sometimes supported with secondary permeability from drilling damage and leaky sealing materials. Moreover, radioactive heating can pressurize connate water around the boreholes and create the initial potential for fluid flow, and buoyant thermal convection will maintain flows over longer times (e.g., [49]). Weathering zones could be crucial unfavourable factor in the CPBS due to geological history. During entire Palaeogene the most basement surface was exposed mostly in continental facies subdued to strong weathering and developing thick breccia lithofacies. Such lithology, if not cemented later, make possible the strong and continuous migration through long geological time, even until Quaternary (when hydrocarbon migration happened in the COBS). it is proven with numerous discovered hydrocarbon reservoirs where oil and gas are found in single hydrodynamic units, simultaneously encompasses pre-Neogene basement and Badenian coarse-grained clastites.

\subsection{Probability classes in proposed categories}

In theory, each category in proposed PoS for the DBD can be evaluated in probability range 0-1. The final decision always is made by expert. However, standardization can be set using certain geological classes with the same probabilities that reflect the attitude of completeness for observed variable in the virtually "infinity" number of measurements. Such categorisation is previously done for hydrocarbon systems in the CPBS (Figure 1.1, Table 1.2) and can be used also in this modification. In such case, all variables are defined with the following values: 1.00 for proven, 0.75 for highly reliable, 0.50 for fairly reliable, 0.25 for unreliable, 0.05 for an undefined variable and 0.00 for nonexistent variable. The further researching and analyses of particular structure case studies could lead to modification of numbers and values of such probability classes.

\section{Conclusions}

This paper presents a PoS modification, intending to assess the safety of geological environment in deep wells where depleted radioactive fuel would be disposed in the pre-Neogene basement of the CPBS. This is a subject of enormous importance, encompassing the case study of the magmatic and metamorphic rocks in that area at regional level.

Two main assumptions of both promising structures for waste disposal and promising lithostratigraphic units with low petrophysical values for the selection of favourable geological units for radioactive waste disposal, are initially established. Considering the proposed modification to PoS with the above assumptions, the classical PoS table is re-assessed. Categories not fitting the scope of radioactive waste disposal are removed and new ones are created. Proposed categories and parameters for modified PoS to be applied for radioactive waste disposal in the Northern Croatia are (a) temperature, (b) isolator properties of rocks and sealings, (c) low petrophysical values + fault zone(s) inactivity and (d) subsurface fluids and aquifers. Probabilities for each category risk can range between 0.0 and 1.0. Value 1.0 is added if all subcategory criteria are completely satisfied at the most favourable level. Value 0.05 is added if none of the criteria is matched in structure due to lack of data. Value 0.0 is added if data confirmed that variable criteria are not fulfilled. The selection of probability is proposed from one of descriptive category, selected by expert, as follows: 1.00 for proven, 0.75 for highly reliable, 0.50 for fairly reliable, 0.25 for unreliable and 0.05 for an undefined variable. 
This modification of PoS is regional one. No one case study with purpose of the DBD for HLW still is not studied, So, the first step is several several deep structures in pre-Neogene basement in the Drava and Sava Depressions, based on palaeostructural maps. Each of them needs to be evaluate with proposed methodology and ranked. Such evaluation would also be some kind of benchmark of methodology itself and make possible to improve categories as well as selection of critical variables inside them.

Further development of the DBD programme in Croatia depends, for sure, on several researching activities, mostly connected with deep drilling and laboratory measurements. It is necessary to create database of the basement rock geomechanical properties, regionally and especially for the most promising mapped structures. Regional stress, present-day and in the past, must be known as well as such values for geothermal heat flux and gradient variations. The sealing borehole techniques must be tested at the samples from the Northern Croatia basement. The historical the strongest earthquake activity maps would be made as well as palinspastic reconstruction of the major fault zones in depressions.

Author Contributions: Conceptualization, T.M., M.B., J.V., M.A.P.D., J.S. and Ž.V; Formal analysis, M.B., J.I. Investigation, U.B., M.A.P.D., M.B..; Software, J.I. and M.B.; Supervision, T.M., J.V. and J.S.; Validation, T.M.; Visualization, M.B. and J.I.; Writing - original draft, T.M., M.B., J.I., J.S., U.B., M.A.P.D., H.F.P.S.; Writing - review and editing, T.M. All authors have read and agreed to the published version of the manuscript.

Funding: This research received no external funding.

Acknowledgments: The authors are grateful for partial support from the project "Mathematical methods in geology IV" (led by T.M.). Funds were given from the University of Zagreb, for the year 2019.

Conflicts of Interest: The authors declare no conflict of interest.

\section{References}

1. Malvić, T. Oil-Geological Relations and Probability of Discovering New Hydrocarbon Reserves in the Bjelovar Sag. Ph.D. Thesis, University of Zagreb, Faculty of Mining, Geology and Petroleum Engineering, Zagreb, Croatia, 2003. (in Croatian, with Abstract in English)

2. Malvić, T. Stochastical approach in deterministic calculation of geological risk-theory and example. Nafta 2009, 60, 658-662.

3. Malvić, T.; Rusan, I. Investment risk assessment of potential hydrocarbon discoveries in a mature basin. Case study from the Bjelovar Sub-Basin, Croatia. Oil GasEur. Mag. 2009, 35, 67-72.

4. Malvić, T.; Velić, J. Stochastically improved methodology for probability of success (POS) calculation in hydrocarbon systems. RMZ - Materials and Geoenvironment 2015, 62, 149-155.

5. Novak Mavar, K. Surface transportation modelling and geological aspects of carbon-dioxide storage into northern Croatian Neogene sandstone reservoirs, case study Ivanić field. Ph.D. Thesis, University of Zagreb, Zagreb, Croatia, 2015. (in Croatian, with Abstract in English)

6. Malvić, T.; Velić, J.; Režić, M. Geological probability calculation of new gas discoveries in wider area of Ivana and Ika Gas Fields, Northern Adriatic, Croatia. RMZ - Materials and Geoenvironment 2016, 63, 127-138. https://doi.org/10.1515/rmzmag-2016-0012

7. Režić, M.; Varenina, A. A new freeware program for the Probability of Success calculation of new gas discoveries within the Croatian part of the Po depression. Rud. Geol. Naft. Zb. 2017, 32, 49-55. https://doi.org/10.17794/rgn.2017.2.6

8. Ivšinović, J. Selection and geomathematical calculation of variables for sets with less than 50 data regarding the creation of an improved subsurface model, case study from the western part of the Sava Depression. Ph.D. Thesis, University of Zagreb, Faculty of Mining, Geology and Petroleum Engineering, 2019. (in Croatian, with Abstract in English)

9. Malvić, T.; Ivšinović, J.; Velić, J.; Sremac, J.; Barudžija, U. Increasing Efficiency of Field Water Re-Injection during Water-Flooding in Mature Hydrocarbon Reservoirs: A Case Study from the Sava Depression, Northern Croatia. Sustainability 2020, 12, 786. - https://doi.org/10.3390/su12030786

10. Geological Map of the Republic of Croatia at a scale 1:300.000. Croatian Geological Survey, Zagreb, 2009. (webGIS service: http://webgis.hgi-cgs.hr/gk300/default.aspx) (in Croatian) 
11. Guide to the Geological Map of the Republic of Croatia at a scale 1:300.000. Velić, I.; Vlahović, I. (eds.); Croatian Geological Survey, Zagreb, 2009, pp. 141. (in Croatian)

12. Šikić, K. Prikaz geološke građe Medvednice [Overview of geological structure of the Medvednica Mt.]. In: Šikić, K. (ed), Geološki vodič Medvednice [Geological Guide for Medvednica Mt.], Croatian Geol. Institute \& INA Petroleum Comp., 1995, Zagreb, 7-40. (in Croatian)

13. Fuček, L.; Tišljar, J.; Sokač, B.; Prtoljan, B.; Oštrić, N. Upper Triassic dolomites in Podsused Quarry (Stop 1). In: Šikić, M. (ed.): Geological Guide for Medvednica Mt. Croatian Geological Institute \& INA Petroleum Comp., 1995, 41-43, Zagreb. (in Croatian)

14. Tomljenović, B. Structural characteristics of Medvednica and Samoborsko gorje Mountains. Ph.D. Thesis, University of Zagreb, Faculty of Mining, Geology and Petroleum Engineering, Zagreb, 2002. (in Croatian, with Abstract in English)

15. Maričić, A.; Starčević, K.; Barudžija, U. Physical and mechanical properties of dolomites related to sedimentary and diagenetic features - case study of the Upper Triassic dolomites from Medvednica and Samobor Mts., NW Croatia. Rudarsko-Geološko-Naftni Zbornik, 2018, 33, 3, 33-44. https://doi.org/10.17794/rgn.2018.3.4

16. Grgasović, T. Stratigraphy of the Upper Triassic deposits of Žumberak, M.Sc. Thesis, University of ZagrebFaculty of Science, 1998. (in Croatian, with Abstract in English)

17. Pavičić, I.; Dragičević, I.; Vlahović, T.; Grgasović, T. Fractal analysis of fracture systems in Upper Triassic Dolomites in Žumberak Mountain, Croatia. Rudarsko-Geološko-Naftni Zbornik 2017, 32, 3, 1-13. https://doi.org/10.17794/rgn.2017.3.1

18. Barudžija, U.; Velić, J.; Malvić, T.; Trenc, N.; Matovinović Božinović, N. Morphometric Characteristics, Shapes and Provenance of Holocene Pebbles from the Sava River Gravels (Zagreb, Croatia). Geosciences, 2020, 10(3), 92; https://doi.org/10.3390/geosciences10030092

19. Barudžija, U.; Bočić, N.; Macek, K.; Repinc, I.; Smirčić, D. Triassic carbonate complex of the Papuk Mts. (Outcrops along Velika - Slatinski Drenovac road). In: Horvat, M. \& Galović, L. (Eds.) 5th Croatian Geological Congress - Fieldtrip guidebook. Zagreb, Croatian Geological Survey, 2015, 55-64, Zagreb.

20. Šegvić, B. Petrology and geochemistry of the greenschists from the central part of the Medvednica Mts. M.S. Thesis, University of Zagreb, Faculty of Mining, Geology and Petroleum Engineering, Zagreb, 2003. (in Croatian, with Abstract in English)

21. Mišur, I. Geodinamic evolution of low-grade metamorphism metasedimentary rocks in the Medvednica Mts. Ph.D. Thesis, University of Zagreb, Faculty of Science, Zagreb, 2017. (in Croatian, with Abstract in English)

22. Šuica, S. Granitoids of the Pannonian Basin basement in the Eastern Croatia. Ph.D. Thesis, University of Zagreb, Faculty of Mining, Geology and Petroleum Engineering, Zagreb, 2019. (in Croatian, with Abstract in English)

23. Malvić, T. Strukturni i tektonski odnosi te značajke ugljikovodika širega područja naftnoga polja GalovacPavljani [Structural and tectonic relations and characteristics of hydrocarbons in the wider area of the GalovacPavljani oil field]. MSc. Thesis, University of Zagreb, Faculty of Mining, Geology and Petroleum Engineering, Zagreb, Croatia, 1998. (in Croatian, with Abstract in English)

24. Malvić, T. Regional geological settings and hydrocarbon potential of Bjelovar sag (subdepression), R. Croatia. Nafta 2004, 55, 273-288.

25. Malvić, T. Review of Miocene shallow marine and lacustrine depositional environments in Northern Croatia. Geological quarterly 2012, 56, 493-504. - https://doi.org/10.7306/gq.1035

26. Pavelic, D. Tectonostratigraphic model for the North Croatian and North Bosnian sector of the Miocene Pannonian Basin System. Basin Research 2001, 13, 359-376. doi: 10.1046/j.0950-091x.2001.00155.x.

27. Pavelic, D.; Miknic, M.; Sarkotic Slat, M. Early to Middle Miocene facies succession in lacustrine and marine environments on the southwestern margin of the Pannonian basin system. Geologica Carpathica 1998, 49, 433-443.

28. Vrbanac, B. Paleostrukturne i sedimentološke analize gornjopanonskih naslaga formacije Ivanić grad u savskoj depresiji [Paleostructural and sedimentological analyzes of the Upper Pannonian deposits of the Ivanić grad Formation in the Sava Depression]. Ph.D. Thesis, University of Zagreb, The Faculty of Science, 1996. (in Croatian, with Abstract in English)

29. Prelogovic, E. Neotektonska karta SR Hrvatske [Neotectonic map of SR Croatia], Geološki vjesnik 1975, 28, 97108. (in Croatian)

30. Malvić, T.; Cvetković, M. Lithostratigraphic units in the Drava Depression (Croatian and Hungarian parts) a correlation. Nafta 2013, 64, 1, 27-33.

31. Malvić, T. Geological maps of Neogene sediments in the Bjelovar Subdepression (northern Croatia). Journal of Maps 2011, 304-317. - https://doi.org/10.4113/jom.2011.1185 
32. Pandžić, J. Podloga tercijara jugozapadnog dijela Panonskog bazena [Tertiary base of the southwestern part of the Pannonian Basin]. Proceedings of the IV. god. znanstvenog skupa I. sekc. ZSN JAZU - Stubičke Toplice, Croatia, 1978., pp. 33-44, Zagreb. (in Croatian)

33. Hernitz, Z. Dubinski strukturno-tektonski odnosi u području istočne Slavonije [Deep structural-tectonic relations in the area of Eastern Slavonia]. Ph.D. Thesis, University of Zagreb, Zagreb, Croatia, 1983. (in Croatian)

34. Malvić, T. Geološki odnosi područja Virovitica-Rezovačke Krčevine-Orešac [Geological relations of the area Virovitica-Rezovačke Krčevine-Orešac]. Graduate Thesis, University of Zagreb, Faculty of Mining, Geology and Petroleum Engineering, Zagreb, Croatia, 1995. (in Croatian, with Abstract in English)

35. Malvić, T.; Sučić, A.; Cvetković, M.; Resanović, F.; Velić, J. Low permeability Neogene lithofacies in Northern Croatia as potential unconventional hydrocarbon reservoirs. Central European Journal of Geosciences 2014, 6 , 2, 182-194. - https://doi.org/10.2478/s13533-012-0168-x

36. Cota, L.; Britvić, V. Hidrodinamika i kemizam formacijskih voda Dravske potoline - Panonski bazen [Hydrodynamic and chemistry of Drava Depression formation waters - Pannonian Basin]. Nafta 1991, 42, 4, 121-136, Zagreb. (in Croatian, with Abstract in English)

37. Malvić, T. Ležišne vode naftnoga polja Galovac-Pavljani [Field water of the Galovac-Pavljani Field]. Hrvatske vode 1999, 7, 139-148. (in Croatian).

38. Malvić, T.; Velić, J. Relation between Effective Thickness, Gas Production and Porosity in Heterogeneous Reservoirs: an Example from the Molve Field, Croatian Pannonian Basin. Petroleum geoscience 2010, 16, 1, 41-51. - https://doi.org/10.1144/1354-079309-722

39. White, D., A. Geologic Risking Guide for Prospects and Plays. AAPG Bulletin 1993, 77/12, 2048-2061. https://doi.org/10.1306/bdff8fce-1718-11d7-8645000102c1865d

40. Hernitz, Z.; Bokor, N.; Malvić, T. Probability Evaluation of New Hydrocarbon Finds in Some Parts of Sava and Drava Depression. Working materials of the 2nd Int. Symposium on Petroleum Geology, Zagreb, Croatia, April 22-24, 1999; pp. 165-175.

41. Malvić, T.; Rusan, I. Potential hydrocarbon discoveries in Bjelovar Subdepression, Croatia. Search and Discovery 2007, 9, 1-6.

42. Malvić, T.; Rusan, I. Investment risk assessment of potential hydrocarbon discoveries in a mature basin. Case study from the Bjelovar Sub-Basin, Croatia. Oil, gas - European Magazine (Hamburg) 2009, 35, 67-72.

43. Beswick, A. J.; Gibb, F. G. F.; Travis, K. P. Deep borehole disposal of nuclear waste: Engineering challenges. Energy 2014, 167, 2, 47-66. - https://doi.org/ 0.1680/ener.13.00016

44. Wang, J. On area-specific underground research laboratory for geological disposal of high-level radioactive waste in China. Journal of Rock Mechanics and Geotechnical Engineering 2014, 6, 2, 99-104.

45. Zhao, X.G.; Wang, J.; Qin, X.; Cai, M.; Su, R.; He, J.; Zong, Z.; Ma, L.; Ji, R.; Zhang, M.; Zhang, S.; Yun, L.; Chen, Q.; Niu, L.; An, Q. In-situ Stress Measurements and Regional Stress Field Assessment in the Xinjiang Candidate Area for China's HLW Disposal. Engineering Geology 2015, 197, 42-56.

46. Gibb F.G.F.; Travis K.P.; McTaggart, N.A.; Burley, D,; Hesketh; K.W. High density support matrices: key to deep borehole disposal of spent nuclear fuel. Journal of Nuclear Materials 2008c, 374, 3, 370-377.

47. Macenić, M.; Kurevija, T.; Strpić, K. Systematic review of research and utilization of shallow geothermal energy in Croatia. Rudarsko-geološko-naftni zbornik 2018, 33, 5, 37-46. https://doi.org/10.17794/rgn.2018.5.4

48. Borović, S.; Marković, T.; Larva, O.; Brkić, Ž.; Mraz, V. (2016): Mineral and Thermal Waters in the Croatian Part of the Pannonian Basin. In: Papić, P. (ed.): Mineral and Thermal Waters of Southeastern Europe. 174 p., Springer, 2016, 31-45.

49. Franklin, W.S.; Yongje, K.; Byung-Gon, C. Deep Borehole Disposal of Nuclear Wastes: Opportunities and Challenges. J. Nucl. Fuel Cycle Waste Technol 2017, 15, 4, 301-312. https://doi.org/10.7733/jnfcwt.2017.15.4.301

50. U.S. Nuclear Waste Technical Review Board (NWTRB). Technical evaluation of the U.S. Department of Energy deep borehole disposal research and development program. A Report to the U.S. Congress and the Secretary of Energy, 2016, $32+$ Appendices.

51. Tatarinov, V.N.; Morozov, V.N.; Manevich, A.I.; Tatarinova, T.A. Underground Research Laboratory: to the Program of Geomechanical Research. Radioactive Waste 2019, 2, 7, 82-96. https://doi.org/10.25283/2587-97072019-2-101-118

52. Gibb, F.G.F.; Travis, K.P.; McTaggart, N.A.; Burley, D. A model for heat flow in deep borehole disposals of high-level nuclear waste. Journal of Geophysical Research 2008b, 113, 5, B05201. https://doi.org/10.1029/2007JB005081

53. Gibb, F.G.F.; Travis, K.P.; Hesketh, K.W. Deep borehole disposal of higher burn up spent nuclear fuels. Mineralogical Magazine 2012, 76, 8, 3003-3017. 
54. Brady, P.V.; Arnold, B.W.; Freeze, G.A.; Swift, P.N.; Bauer, S.J.; Kanney, J.L.; Rechard, R.P.; Stein, J.S. Deep borehole disposal of high-Level radioactive waste. SAND2009-4401, Sandia National Laboratories, Albuquerque, 2009, 74 . 